Open Access

\title{
Barriers to innovation: the case of Ghana and implications for developing countries
}

\author{
Frank L. Bartels, Ritin Koria and Elisa Vitali ${ }^{*}$ (i)
}

\author{
*Correspondence: vitalielisa@alice.it \\ Vienna International Centre, United \\ Nations Industrial Development \\ Organization (UNIDO), \\ Wagramerstrasse 5, PO BOX 300, \\ 1400 Vienna, Austria
}

\begin{abstract}
This paper analyses the barriers to innovation and innovativeness in the Ghana National System of Innovation (GNSI) in terms of the quadrilateral relationships between the following four actors: (a) government; (b) medium- and high-technology industries; (c) knowledge-based institutions; and (d) arbitrageurs (venture capital, finance capital and knowledge brokers). The paper contributes to research on systems of innovation in view of the wide recognition of the importance of National System of Innovation (NSI) for economic performance. The barriers to innovation in Ghana identified, through factor analysis, provide a framework to isolate systemic problems and enable policy makers to enhance effective policy delivery at the system level. This empowers the four actors to overcome the specific barriers to innovation and thus enabling the overall GNSI, through increased effectiveness and efficiency, to achieve higher levels of competitiveness. We find that barriers to innovation and innovativeness in Ghana factor significantly into the following: skills-Information and Communication Technology (ICT) capability/capacity; unsophisticated markets; deficient fiscal policy; and organisational risks.
\end{abstract}

Keywords: Innovation, National Systems of Innovation, Innovation policy, Quadruple helix

\section{Resumen}

Este artículo analiza las barreras a la innovación e inventiva en el Sistema Nacional de Innovación Ghana (SNIG) en términos de las relaciones entre los siguientes cuatro actores: a) gobierno, b) industria de la media y alta tecnología, c) instituciones del conocimiento, y d) árbitros (capital de riesgo, el capital financiero, y agentes del conocimiento). El documento contribuye a la literatura de los sistemas nacionales de innovación en vista del amplio reconocimiento de su importancia para el crecimiento de la economía. Las barreras a la innovación en Ghana, identificadas mediante análisis factorial, proporcionan un marco conceptual para identificar problemas sistémicos y así mejorar la formulación y ejecución de políticas públicas. Esto permite a los cuatro actores mencionados superar las barreras específicas para la innovación y al GNSI en general lograr mayores niveles de competitividad. Nuestros resultados muestran que las siguiente barreras a la innovación (y a la capacidad de innovación) son importantes: Capacidad de las tecnología de la comunicación, mercados no sofisticados, política fiscal deficiente; y riesgos organizacionales. 


\section{Résumé}

L'article analyse les barrières à l'innovation et à la capacité d'innover dans le Système national d'innovation du Ghana en termes de relations quadrilatérales entre les acteurs que sont a) le Gouvernement, b) les entreprises de moyenne et haute technologie, c) les institutions basées sur la connaissance, et d) les arbitragistes (capital-risque, capital financier, et courtiers de la connaissance). L'article contribue à la recherche sur les systèmes d'innovation compte tenu de la large reconnaissance de l'importance des Systèmes nationaux d'innovation pour la performance économique. Les barrières à l'innovation au Ghana, identifiées par analyse factorielle, fournissent un cadre pour isoler les problèmes systémiques et permettre aux décideurs politiques d'améliorer l'efficacité des prestations au niveau des systèmes. Ce qui permet aux quatre acteurs de surmonter les obstacles spécifiques à l'innovation permettant ainsi à l'ensemble du système par une plus grande efficacité d'atteindre de très bons niveaux de compétitivité. Nous avons constaté que les barrières à l'innovation et à la capacité d'innover au Ghana relèvent principalement des compétences en technologies de l'information et de la communication, des marchés non organisés, des politiques fiscales inadéquates et des risques organisationnels.

\section{摘要}

利用下述四个主体的四边关系:1)政府 2)中高技术产业 3)知识型机构 4)套利商(风 险资本、金融资本和知识经纪人)，本文分析了在加纳国家创新体系(GNSI)中创新 和创新能力方面的障碍。鉴于对国家创新体系(NSI)对经济发展贡献的重要性的 广泛认可, 本文有助于对创新体系的研究。通过因子分析而确认的加纳创新障 碍，为离析体系问题提供了框架，在制度层面使政策制定者能加强有效的政策颁 布。这赋予四个主体克服创新障碍的能力，从而使整个GNSI能通过提高效益和效 率取得更大的竞争力。我们发现在加纳的创新和创新能力方面的障碍包括:技能信息和通信技术 $(I C T)$ 性能/容量，不成熟的市场,缺乏财政政策和组织的风险。

\section{Аннотация}

В настоящей работе исследуются барьеры инноваций и инновационности на примере Национальной инновационной системы Ганы в рамках четырехспиральных взаимосвязей между следующими акторами: а) Правительство; б) Средне- и Высокотехнологичные производства; в) Исследовательские институты; и г) Арбитражеры (венчурные фонды, инвестиционные фонды и посредники на рынке знаний). Статья посвящена исследованию инновационной системы в контексте более широкой оценки вклада Национальной инновационной системы в экономическое развитие. Барьеры инноваций на примере Ганы определены методом Факторного анализа, по итогам которого была разработана модель, характеризующая проблемы изолированных систем, и предложены рекомендации по улучшению действующего законодательства на государственном уровне. Это позволит четырем акторам преодолеть специфические барьеры инноваций и тем самым позволит Национальной инновационной системе Ганы стать более конкурентоспособной за счет более высокой эффективности. Мы считаем, что барьеры инноваций и инновационности, выявленные на примере Ганы, сопровождают следующие экономические явления: Информационнокоммуникационные технологии (ICT); неразвитые рынки; несовершенная финансовая политика; организационные риски. 


\section{Resumo}

Esse artigo analisa as barreiras para a inovação e para a capacidade de inovar no Sistema Nacional Inovação de Ghana (Ghana National System of Innovation -GNSI) em termos do relacionamento quadrilateral entre os seguintes atores : a)Governo; b) Industria de Media e Alta Tecnologia; c)Instituições baseadas no conhecimento; e d) Arbitradores (capital de risco, o capital financeiro, e corretores de conhecimento). O artigo contribui para pesquisas sobre sistemas de inovação tendo em vista o amplo reconhecimento da importância do Sistema Nacional de Inovação (National Systems of Innovation -NSI) para o desenvolvimento econômico. As barreiras da inovação indentificadas em Ghana, através da Análise de Fatores, fornece um quadro que isola os problemas sistêmicos e permite aos tomadores de decisão a melhoria da entrega de políticas eficazes no nível do sistema. Isso permite que os quatro atores superem as barreiras específicas da inovação assim como o GNSI, através de uma maior eficácia e eficiência, para alcançar níveis mais elevados de competitividade. Nós descobrimos que os obstáculos à inovação e à inovatividade no caso de Ghana são: Competências das Informações; Tecnologias de Comunicação (Communication Technology -ICT); Aptidão/Capacidade; Mercados pouco sofisticadas; Políticas Fiscais deficientes; e Riscos Organizacionais.

\section{Multilingual abstract}

Please see Additional file 1 for translation of the abstract into Arabic.

\section{Introduction}

The significance to policy makers of the systemic approach for policy management of innovation as key to national development in the context of the knowledge-based economy is increasingly evident (Bartels et al. 2012; Cooke and Leydesdorff 2006; Fagerberg et al. 2010; Penrose 1959). The production, accumulation and distribution (explicitly and tacitly) of knowledge through institutions, networks and assets of organisational, human and social capital remain the salient characteristic of innovation. Knowledge remains the essential driving mechanism for economic and competitive advancement (Bartels and Lederer 2009; Bush, 1945; Delgado et al. 2012; European Research Council Expert Group 2003; Subramaniam and Youndt 2005).

Knowledge, in its scientific and technological manifestations, refers not only to the codifiable, covert and explicit elements of comprehension that can be transferred extrinsically by learning, hard copy and skills but also to the tacit and implicit components of understanding held intrinsically in individuals, epistemic communities of practice and collective experience (Tidd and Izumimoto 2002). In order to enhance national competitive advantage (Bartels et al. 2009) through exploiting both forms, it is crucial for policy makers in governments to utilise effectively and efficiently extant policy instruments and to design new policies-based on empirical evidence-as a function of significant variables. Such variables should be configured and calibrated to overcome barriers to innovation (Cai 2011). The current fragmented approaches to policy management of innovation are hallmarked by a palpable lack of attention to the network and relationship characteristics of innovation (Tidd 1997, 2001, 2006). This policy deficiency is persistent (Adams et al. 2006; Arnold 2004; Hidalgo and Albors 2008). All countries have a National System of Innovation (NSI), effective and efficient to a differing extent, and as the NSI of a country is crucial to its economic performance 
(Bartels and Voss 2005; Cooke and Morgan 1999; Florida 2005; Malecki 1997), it is germane to map and measure NSI and specifically to identify the significant barriers to innovation, in order to enable policy makers to improve policy on innovation.

Current debates on policy are orientating research, technology and innovation policy towards societal challenges, rather than solely towards economic growth objectives. There is a demand for new lines of argumentation to systematically legitimise policy interventions (Weber and Rohracher 2012). To date, in systems of innovation literature, there have been two contrasting views to the rationale for policy intervention. The first is the market failure rationale, which is considered to be valid although provides insufficient justification for policy intervention. This therefore needs to be bolstered by the second which is systemic failure rationale (Bleda and Del Rio 2013). The realisation that "elaboration of notions of systems failure, rather than just market failure, can further improve policy-making in the future" (Dodgeson et al. 2011, p. 1145), particularly taking into account the unique problems faced by each country. Phrased differently there is the need "to move from one-size-fits all policies to policies that take into account the specificities of the system" (Chaminade et al. 2008, p. 1). Both developed and developing countries face different issues in enabling them to innovate with the scope and extent of problems being rather different in both contexts. With this in mind, it is imperative that in developing countries policy makers understand the structure of their NSI in terms of the underlying factors that determine the behaviour of actors and the functioning of the NSI. Thus, analysis and identification of the significant barriers to innovation and innovativeness can lead to well-calibrated innovation policies (Bartels et al. 2012, 2013). Institutions are pivotal in creating the appropriate environment to support markets and market transactions, which, subsequently, sustain the NSI. However, the study of NSI for policy purposes is challenging for the following reasons: uncertainty and the complex adaptive system (CAS) nature of NSI (Holland 2006; Lane and Maxfield 2004); the problematic of modularity i.e. the selection of unit(s) of analysis; and evolution in terms of capturing the state of NSI when it is most stable and representative.

This paper targets policy makers and focuses on the systems of innovation approach. First, it contributes to the current debate on NSI in developing countries in general and Ghana specifically by providing a framework that identifies significant barriers to innovation empirically through factor analysis. Second, it increases the awareness of these factors to enable policy makers to incentivise government, medium- and hightech industries (MHTI), knowledge-based institutions (KBIs) and arbitrageurs to meet higher resolution standards by innovating, adopting new technology and changing their behavioural patterns with respect to connectedness. Third, it fills a gap in the literature characterised by a noticeable lack of studies that use factor analysis in examining NSI (Becheikh et al. 2006). Fourth, it addresses the lacunae in the literature regarding studies of NSI in developing countries. Fifth, it presents the significant barriers to innovation in Ghana and indicates implications for developing countries.

The rest of the paper is organised as follows. The next section provides a comprehensive overview of the literature on the empirical approaches to, and the concept of, NSI; "Country level context" section provides the country level context. "Methodological approach-factor analysis" section addresses the approach of our analysis and indicates data characteristics. "Results and discussion of the main barriers to innovation" section 
presents results, findings and discussion of the factor analysis. "Policy recommendations and concluding remarks" section concludes the paper.

\section{Literature review of National System of Innovation (NSI)}

Despite the wealth of contributions to examining NSI, it is arguable that "after more than 30 years of research on innovation and organisational outcomes, fundamental concepts and units of analysis are often confused and/or ambiguous" (Gatignon et al. 2001, p. 2). The heterogeneity of systems of innovation continues to evoke debate regarding functions, activities and factors that animate a particular system and whether these are dominated by learning (the Aalborg-OECD tradition) (Lundvall 2007) or systemic structural relations (the Triple Helix tradition) (Edquist 2010; Leydesdorff 2012).

However, statistical assessments that use factor analysis to scrutinise NSI are relatively few (Bartels et al. 2012; Chang and Lin 2012). This is due to the challenges of measurement and complexities that arise from the geographical spatiality of firms, industrial agglomeration and territorial clusters (Amin and Cohendet 2005). Until the early 1990s, the vast majority of surveys on innovation reported, as the principle source of analytical information and statistics, frequencies or correlations (Patel and Pavitt 1994). Moreover, empirical approaches have focused mostly on developed countries. ${ }^{1}$ The orientation towards studies of NSI in developed countries persists. Analysis of empirical studies of innovation, in the decade 1993-2003, shows that $84 \%$ of articles investigated North American and European countries (Becheikh et al. 2006). In addition, the main topic of analysis has been the sectoral level of the innovation system and concerns overwhelmingly the firm without considering nested levels of the NSI which provides a complete view of the innovation system.

Notable exceptions in this lacuna are Cai (2011), Chaminade et al. (2012), who run factor analysis to model NSI and Da Motta and Albuquerque (1999), Gatignon et al. (2001, 2002), Nasierowski and Arcelus (1999), and also Nooteboom et al. (1998). Albuquerque et al. (2015) have also used factor analysis as a tool to look at university industry linkages within the context of developing national systems of innovation in China. Fagerberg and Srholec (2008) used factor analysis on 25 indicators and 115 countries between 1992 and 2004 in order to study the role of capabilities for economic development. Since the early 1990s, the incidence of frequency and correlation analyses has remained significant accounting for $27 \%$ in comparison to regression analyses at $80 \%$ in empirical work on innovation (Becheikh et al. 2006). The focus continues to be on firms as the unit of analysis rather that the four actors in the NSI (Bartels and Koria 2012 (GNSI Report); Koria and Köszegi 2011; Koria et al. 2013).

Given the systemic properties of innovation (Fagerberg 2005) and its socio-technical nature (Geels 2004), the concept of the national system of innovation is best appreciated as one taxon, albeit a central one, among several within the broader notion of systems of innovation (Edquist 1997, 2005a, 2005b). The concept National Systems of Innovation or National Innovation Systems has been used widely since the 1980 s. $^{2}$ However, the provenance of the operative core of the concept is found in the economic analyses of Abramovitz (1986), Keynes (1936), List (1841), Ricardo (1817), Romer (1986), Schumpeter (1934), Smith (1776), Solow (1956) and Veblen (1898). We prefer the term National System of Innovation. The semantic difference is important. Our preference underscores the emphasis on the System of Innovation manifest at the level 
of national economic policy, coordination and organisation (Bartels and Koria 2013; Lundvall 2004). The evolution of definitions of NSI (Koria and Köszegi 2011) indicates recurrent elemental features such as skills and knowledge transfer through interactions between core actors and their networks. Also, effective and efficient flows of new technology and information within, and among, public and private sectors, enterprises, universities, researchers and government agencies cohered by institutions are seen as definitive to innovativeness and the process of innovation manifest at the level of the national economy (Organisation for Economic Co-operation and Development [OECD] 1997).

The operative core of NSI consists of linkages (formal and informal), and their distribution and intensity, between and within institutions that facilitate intellectual flows and exchange of knowledge resources in the economy (Buckley and Carter 2004). Herein, institutions are interpreted bilaterally as organisations as well as the "rules of the games" (North 1990). According to Freeman (1987), NSI is the network of public and private sector institutions whose activities and interactions dynamise new technologies and innovative performance (Edquist and Lundvall 1993; Nelson and Rosenberg 1993). Lundvall (1992) defined NSI as the location-bound elements and relationships interacting in the production, diffusion and use of new, and economically useful, knowledge. Patel and Pavitt (1994) described NSI as the incentive structures and competencies of national institutions that determine the vector of technological learning and change in a country. There are many definitions of NSI (Achim and Popescu 2009; Bartels and Koria 2012; Bartels et al. 2012; Tidd 2006). We define the NSI as "the envelope of conforming policies as well as private and public organisations, their distributed institutional relations, and their coherent social and capital formations, that determine the vector of technological change, learning and application in the national economy" (Bartels et al. 2012, p. 6).

As indicated by Leydesdorff and Etzkowitz (1996), these recurrent NSI features, distilled into the strength and quality of interactions between actors, are pivotal in determining effectiveness and efficiency in the creation and dissemination of knowledge (Asheim and Gertler 2005). The dynamics of knowledge and the spatial concentration of economic relations are ultimately based on intellectual assets (Cohen et al. 2000; Nahapiet and Ghoshal 1998; Piekkola 2006, 2011). A direct consequence of this is that NSI are prevalent in industrialised and emerging market economies and developing countries aspire to increase innovation to develop their economies. ${ }^{3}$ Therefore, empirical understanding of NSI carries significant implications for developing countries (Bartels and Lederer 2009). However, from the perspective of developing countries, the implications have to be seen through the local cultural and institutional lenses of the 'South' (Arocena and Sutz 2000a) and it is important to "avoid copying or just following the latest policy fashion" (Arocena and Sutz 2000b, p. 59). They also suggest that there is a "learning divide" and an "innovation gap" between the north and the south. They propose that, in order to overcome this gap, there is the need for strengthening and increasing the diversity of "interactive learning spaces". Using Thailand as a case for illustrating and analysing NSI in countries, which are relatively less successful in catching-up technologically, Intarakumnerd et al. (2002) highlight the crucial importance of enhancing human capital through learning. 
Viotti (2001) in examining the disparities between industrialised and late industrialising nations through a comparative analysis of Brazil and South Korea highlights a potential shortcoming of the NSI approach. He suggests that the process of innovationled technical change is the privilege of industrialised countries, and that the process of technological change witnessed in industrialising countries is through the absorption and improvement of innovations produced in industrialised countries. Viotti (2001) thus proposes National Learning Systems (NLS) where absorption of technologies and incremental innovation are the focus of late industrialising countries. Here, NLS should be centred in the "activities, institutions, and relationships, associated to learning rather than innovation" (Viotti 2001, p. 7).

Contributions to systems of innovation literature, in the context of developing countries and policy, include Intrakumnerdi and Chaminade (2007) who build on the works of Bell (2002). They discuss the rationale for public intervention in innovation systems in the specific socio-economic and institutional context of less successful developing countries, using Thailand as the case. They argue that "while IS might have been 'officially' adopted by less-successful developing countries, the practice still follows old innovation paradigms and barely addresses systemic problems" (Intrakumnerdi and Chaminade 2007, p. 15).

Although there have been several authors who have focused on Latin America and Asia, in recent years, there have been a number of works dedicated to systems of innovation in the African context. Spielman et al. (2008) and Davis et al. (2008) have used systems of innovation as an analytical framework to examine technological change in agriculture. Authors such as Oyelaran-Oyeyinka and Barclay (2004) present a discussion on how historically generated institutions and persistent pattern of human capital formation condition the emergent systems of innovation in Africa.

However, in addition to the above, the handbook of innovation systems and developing countries, edited by Lundvall et al. (2011) provides a critical review of the IS approach and its adequacy for developing countries. It discusses the relationship between systems of innovation and development and addresses the critical question of how it should be adapted to the realities of developing nations.

While this paper focuses exclusively on NSI, the taxonomy of systems of innovation indicates four areas: National, Regional, Sectoral and Technological Systems of Innovation. In addition, the literature discloses Global Systems of Innovation (Archibugi and Iammarino 1999), Continental Innovation Systems (Freeman 2002), Metropolitan Innovation Systems (Fisher et al. 2001) and Spatial Innovation Systems (Oinas and Malecki 2002). Firstly therefore, the architecture of systems of innovation is nested and could be considered as hierarchical (or vertical) organisation with the local form, at the core, encapsulated successively by the metropolitan, regional (subnational), national, spatial (inter-regional or international) and global systems. Secondly, there is the "horizontal" aspect of sector and technological systems of innovation in each of the nested layers. The construct of system of innovation is therefore complex and dynamic and is characterised, at each level, by the emergent features of CAS (Carlisle and McMillan 2006; Holland 1993). Thus, according to Levin (2002, p. 17), "microscopic interactions and evolutionary processes give rise to macroscopic phenomena through nonlinear interactions... subject to path dependence, with... multiple stable states, chaotic dynamics and frozen accidents". Barriers to innovation are therefore crucial factors in these dynamics. 
It is to be noted that the 1999 conference on "National Innovations Systems, Industrial Dynamics and Innovation Policy" (Danish Research Unit for Industrial Dynamics [DRUID] 1999) exposed nine dimensions of NSI. These were methodological, knowledge, learning, organisational, inter-industry and inter-firm linkages, growth and industrial renewal, NSI in developing countries, globalisation and NSI and NSI policy. At the 2012 DRUID Conference (DRUID 2012), 15 dimensions were articulated as systems of innovation, markets and entrepreneurship, organisational strategy and innovation, firm theory and empirics, knowledge networks, intellectual property rights, KBIs and governance, eco-innovations, innovation under financial crises, organisational creativity, institutional dynamics, labour-capital mobility, regional clusters and growth, public-private partnership policy and innovation and economic development. At the DRUID Conference in 2013, 71 parallel sessions with thematic titles ranging from "cluster drivers" to "systems of innovation" enunciated the field of innovation and industrial dynamics. ${ }^{4}$ These dimensions, and the expanding field of coverage, illustrate the evolution of, and dynamics in, the systems of innovation architecture. Similarly, the themes for the 2013 Triple Helix Conference $^{5}$ covered global challenges and growth opportunities, modes of coordination regarding innovation, innovative markets and networks, innovation-friendly financial institutions, interactive patterns in innovation systems, skills for innovation, innovation in the private sector, place-based innovations and local innovations systems. Thus, the two approaches-NSI and Triple Helix-in systematically articulating the role of innovation within industrial dynamics are far from being diametrically opposed. In fact, leading authors in the respective literatures consistently refer to each other's work (Teixeira 2014).

The NSI can therefore be analysed at meta-, macro- and meso-levels. At meta-level, Blanc and Sierra (1999) and Carlsson (2006) highlight the increasing internationalisation of alliances and interrelations between (industry) actors. Within these networks, an important role is played by KBIs, namely universities, private and public research centres, and divisions in international firms, engaged in research-based technoscientific collaborations. These are part of the networks examined in Leydesdorff's (2001) "neo evolutionary" Triple Helix model. At macro-level, decentralisation and social capital are the focus of Bjørnskov and Svendsen (2002) study on the economic performance of Scandinavia. The focus of meso-level and cluster performance analysis is oriented to the importance of the knowledge base, organisational nature, institutional characteristics and involvement in innovation (Asheim and Coenen 2004; Munk and Vintergaard 2004).

Regional Innovation Systems (RIS) are defined by Meesus et al. (1999, p. 9) as "the innovating firms surrounded by a number of actors who are all in one way or another linked to the innovation process of a local firm and to each actor". So, RIS are similar to NSI but the geographical and organisational boundaries are not as precisely defined (Andersson and Karlsson 2004). According to Asheim and Iskasen (2002), RIS could be considered as regional clusters where proximity, in a bounded geographical context, is essential for firms to share and transfer knowledge, human capital, new technologies, capital and cultural norms. These clusters make it possible to exploit externalities, economies of scale and scope and to cooperate in achieving increased regional competitiveness. (Cooke 2002; Florida 1995; Lundvall and Johnson 1994; Morgan 1997; Niosi and Bas 2001). This concept is also reflected by the Triple Helix model. 
Sectoral Innovation Systems (SIS) have been defined by Malerba (2002, p. 248) as the "set of new and established products and the set of agents carrying out market and non-market interactions for the creation, production and sale of those products". Comparing NSI with SIS, the focus in the latter is much more narrow and spatial restrictions are not required since SIS are determined in terms of industry and market structures (Porter 1990). The SIS basic elements are referenced to products in terms of ISIC classification, demand and related links and complementarities as well as to mechanisms of interactions, inter- and intra-firm linkages (in terms of value and supply chains).

Technological Innovation Systems (TIS) refer to technological development represented by R\&D projects, ${ }^{6}$ number of patents, entrepreneurial experimentation (Rosenberg 1996), market formation (Carlsson and Stankiewicz 1991), social acceptance of a new technology (Zimmerman and Zeitz 2002), resource mobilization and positive externalities that arise from supporting and related industries, demand and supply factors (Porter 1990).

The Triple Helix (TH) model (Etzkowitz 2002; Leydesdorff 2005) represents a wellestablished theoretical approach to the study of networks and linkages within, and between, the protagonists of a NSI, which are government, industry and KBIs. It emphasises the role of universities for innovation in increasingly knowledge-based economies. This TH model is analytically different from the Aalborg-OECD approach to NSI (Lundvall 1988, 1992; Nelson 1993). In the Aalborg-OECD tradition, the emphasis is on KBIs. In the TH approach, the main role is played by firms in dynamic interactions with other actors. The TH model of NSI has experienced an evolution; Etzkowitz and Leydesdorff (2000) suggested that there are three types of this model. The type $1 \mathrm{TH}$ demarcates institutionally the three separate spheres of actors, without focusing on the interactions between them, which appear weak and mediated barely by liaison, technology transfer and contract offices. In the type $2 \mathrm{TH}$, attention on actor interrelations shows that mechanisms of communication between the actors are strongly influenced by the market and technological innovations (Bartels et al. 2012; Nelson and Winter 1982). With the type $3 \mathrm{TH}$, a complex network of organisational ties, both formal and informal, among the overlapping actor spheres emerges. The institutional spheres of the three actors as well as the performance of their traditional functions and networks are the focus in third type.

Within the developing country context, the three actors are perceived to hold relatively traditional and separate roles, with little or no overlap in functional relationships, thus avoiding the benefits of exchange from interrelations between actors, such as the knowledge transfer, that represents the basis for development. This is evidenced in developing countries by the lack of bodies such as technology transfer or licensing offices within universities or the absence of venture capitalists (VC). The type $4 \mathrm{TH}$ (Bartels and Koria 2012; Koria and Köszegi 2011; Koria et al. 2012; Leydesdorff 2012) introduces explicitly the fourth actor, namely Arbitrageurs (knowledge brokers, financial institutions, $\mathrm{VC}$ ) indicating the need for access to financial and information resources for an effective and efficient NSI. Arbitrageurs play a crucial role by providing funds, links, knowledge sources and technical knowledge (Howells 2006). To the knowledge of the authors, few empirical analyses of all four actors, either in a developing or industrialised country context, are available. A review of 224 papers, from 
leading institutions working on NSI between 2008 and 2012, indicates only four that delineate NSI in terms of all four actors (Arnold 2011; Kastelle et al. 2009; Mastroeni et al. 2009; Seppänen 2008). However, the approaches therein are not in terms of the type 4 TH according to Bartels and Koria (2012) and Koria and Köszegi (2011) wherein the four actors of the type $4 \mathrm{TH}$ are construed to operate in an environment of diffused Information and Communication Technology (ICT) as illustrated in Fig. 1 below. This type $4 \mathrm{TH}$ represents the underlying model used in this paper for the analytical framework used in to examine barriers to innovation in the Ghana National System of Innovation (GNSI).

\section{Country level context}

In November 2011, Ghana attained middle-income country status (Moss and Majerowicz 2012) due to the generally improved conditions in Africa. Over the last decade, Ghana has been the target of much economic interest. According to the World Bank (2011), the reasons for this include "first, average growth rates of about $5 \%$ since 2000, and over $6 \%$ between 2006 and 2008. Second, significant progress on the [sic] Millennium Development Goals (MDGs). Third, the increasingly attractive investment prospects in Africa's private sector. Fourth, the returns from market-oriented reforms, and fifth, in Ghana's special case, its newly acquired status as an oil producer and exporter" (UNIDO 2013, p. 25). Nevertheless, since 2010, Ghana has seen a reduction in GDP growth from $14.0 \%$ in 2010 to $4.0 \%$ in 2014; an increase in inflation from 13.9 to $16.7 \%$ during the same period and general increase in the export of goods and services as a percentage of GDP from 36.9 to 49.9 \% (World Bank 2016). Currently, the Gross National Income (GNI) per capita equals 1.620US\$ with a total population of 26,79 million (World Bank 2016). Ghana's projected Gross Domestic Product (GDP) growth rate is at around $7 \%$ per annum through to 2016 (Economist Intelligence Unit 2012).

From the perspective of innovation, Ghana has dropped in rank in the global innovation index from 96 out of 141 in 2014 to 108 out of 143 in 2015 (Dutta et al. 2014, 2015). Ghana's gross expenditure on research and development (GERD) as a percentage of GDP rose from $0.23 \%$ in 2007 to $0.38 \%$ in 2010; this figure has remained until 2014 and 2015 due to a limitation of incomplete data (Dutta et al. 2014,

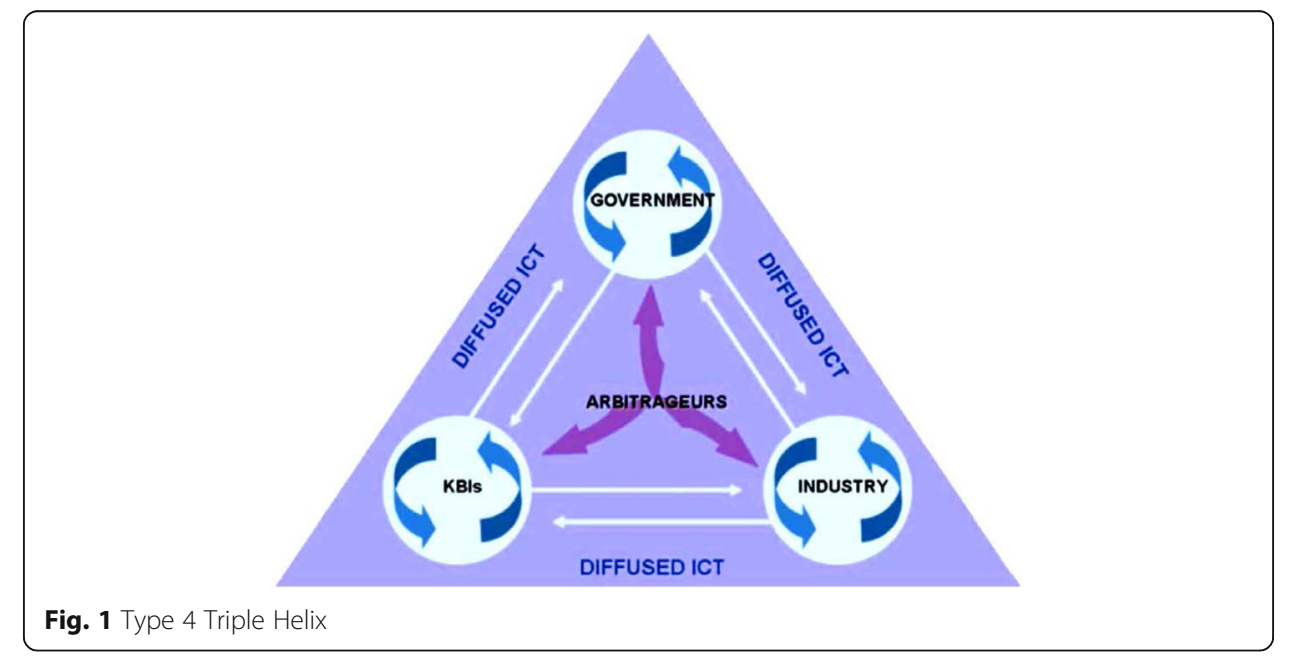


2015). When examining at GERD performed by business enterprise as a percentage of GDP, the world innovation index figures indicate a distinct weakness for both 2014 and 2015 with actual value at 0.00 for both years and the overall ranking dropping from 84 out of 143 to 87 out of 143 .

In terms of researchers per million of population, Ghana ranked 102 out of 143 in 2014 and 94 out of 141 in 2015; this movement shows a positive improvement in creation of skilled human capital. Other relevant innovation-related indicators include ICT access where between $2014^{7}$ and $2015^{8}$, Ghana has moved from 115 out 143 to 92 out of 141 .

It is evident that after two decades of relatively strong and broadly inclusive economic growth which enabled Ghana to reach middle-income status and also helped the country to make significant progress towards the attainment of the MDGs, the country's economic performance has recently weakened, compounded by the sharp drop in oil and commodity prices (Le Billon and Good 2015) and acute power shortages. With this in mind, there is ever more the need for innovation policy to drive growth and vice versa (Mazzucato and Perez 2015); this can only be achieved through a structured evidence-based approach with a view on not only market but the system of innovation in complement (Bleda and Del Rio 2013).

\section{Methodological approach-factor analysis}

The empirical approach to investigate the underlying factors that hinder the development of a proper environment to stimulate innovation and innovativeness, and which are responsible for the poorly articulated linkages between NSI actors in Ghana, uses the analytical technique of exploratory factor analysis (EFA). Factor analysis (exploratory and confirmatory) has an unimpeachable reputation as the "most powerful and flexible tools for assessment of multivariate dependence and co-dependence" (Lopes and West 2004, p. 41). Becheikh et al. (2006, p. 650) refer to empirical studies using "measurements of innovation obtained through a factor analysis of answers to a set of survey questions". In terms of measuring perceptions with respect to innovation-adoption and constructs-Pankratz et al. (2002) and Sauer and O'Donnell (2007) rely on factor analysis for their findings. At the regional level, Martinez-Pellitero et al. (2008) employ factor analysis as a methodological approach, as do Navarro and Gibaja (2009), and Bugge et al. (2011). Finally, the analytical prowess of factor analysis as a statistical instrument for fine-grained research is indicated by Di Stefano et al. (2012).

The variables of this study on barriers to innovation are grouped under the dimension of NSI named barriers to innovation. Bartels and Koria (2012) indicate other dimensions of NSI not addressed in this paper. The variables on barriers to innovation were culled from the NSI literature. ${ }^{9}$ The variables were measured by an electronic survey instrument using a five-point Likert scale ${ }^{10}$, are treated as quantitative parametric data (Labovitz 1967) and are considered valid and reliable as parametric quantitative data (Labovitz 1970, 1971). The variables influenced significantly by factors are indicated in Tables 2, 3, 4 and 5.

The quantitative data was acquired by Free Open Source Software (FOSS) Lime survey, in 2011 by the United Nations Industrial Development Organization (UNIDO), of the four type $4 \mathrm{TH}$ actors. To the knowledge of the authors, this data is the first of its kind to map and measure the NSI using the type $4 \mathrm{TH}$ model. The GNSI survey 
maps and measures, inter alia, the inter- and intra-relationships (institutional linkages, policy proximity, convergence or divergence and connectedness) of respondents from the four NSI actors as well as barriers to innovation. We are primarily concerned with identifying the statistically significant factors that determine barriers to innovation. Therefore, we rely justifiably on quantitative data and employ neither a case approach nor qualitative data as these approaches, while methodologically acceptable elsewhere in social science, have no statistical signification.

\section{Respondents surveyed}

The first category of respondents is the policy community, essentially the Government, represented by high-level officials in public institutions directly related to innovation. These include the Ministries of Science and Technology, Economy, Finance, Education, Trade and Industry. The second category is the KBIs, represented by heads of university innovation-related faculties/departments of economics, science, engineering, technology and business, as well as heads of think tanks and research institutes. Additionally, private funded research institutes are included. The third group consists of the industrial community embodied in the Chief Executive Officers (CEOs) of firms in the medium- and high-technology manufacturing sectors defined according to the UNIDO sectoral ISIC Rev.3 classification. Finally, the fourth group consists of arbitrageurs, represented by financial institutions, venture capitalists and knowledge brokers.

\section{Universe, population and sample}

The surveyed sample of respondents, culled from the universe and population, is indicated in Table 1.

The leadership of policy-making across the four actors in the GNSI is not a large population, and it is crucially important to note that respondents surveyed were from the government (Ministers, Deputy Ministers, Chief Directors), medium- and high-technology manufacturing sectors (CEOs, Deputy CEOs), KBIs (Faculty Deans, Department Heads) and arbitrageurs (CEOs, Deputy CEOs). The returns shown in Table 1 indicate a relatively high survey response rate. Harzing (2006) indicates that in surveys directed towards senior management, the general response rate is at around $30 \%$. Given the high-level respondents, we are confident that high validity, reliability, reproducibility and generalisability arising from the response rate (Zwane et al. 2011) are reinforced by the rigour of the statistical analysis.

Table 1 GNSI universe, population (convenient sample of respondents) and surveyed sample of respondents

\begin{tabular}{|c|c|c|c|c|c|}
\hline Actor & $\begin{array}{l}\text { Universe of } \\
\text { respondents }\end{array}$ & $\begin{array}{l}\text { Population (convenient } \\
\text { sample of accessible } \\
\text { respondents) }\end{array}$ & $\begin{array}{l}\text { Percentage of } \\
\text { universe of } \\
\text { respondents (\%) }\end{array}$ & Survey responses & $\begin{array}{l}\text { Survey response } \\
\text { rate }(\%)\end{array}$ \\
\hline Government & 260 & 166 & 63.8 & 39 & 33.6 \\
\hline $\mathrm{MHTI}$ & 120 & 87 & 70.8 & 60 & 68.9 \\
\hline KBls & 182 & 175 & 96.2 & 129 & 73.3 \\
\hline Arbitrageurs & 16 & 16 & 100 & 6 & 37.5 \\
\hline All actors & 578 & 444 & 76.8 & 234 & 52.7 \\
\hline
\end{tabular}




\section{Statistical operations-exploratory factor analysis (EFA)}

The statistical analysis performed on the data is EFA. According to Everitt (2002, p. 140), factor analysis permits "the correlations or covariance between a set of observed variables, that arise from the relationship of these variables to a small number of underlying, unobservable, latent variables, usually known as the common factors" to be captured. Therefore, there are fewer factors than variables. Exploratory factor analysis reduces the magnitude of data without losing the complexity of NSI. It reduces observed variables into factors within a pattern matrix (clusters of inter-correlated variables) with "mutual interdependence" (Gaur 1997). Phrased differently, factor analysis discloses the latent factors that influence significantly the variation of the variables in the data, in the sample, and hence in the population and in the universe of respondents (Kim and Mueller 1978). The statistically significant confidence level in factor analysis, represented by the Kaiser-Meyer-Olkin (KMO) measure of sampling adequacy, shows the robustness of the sample in terms of distinct and reliable factors extracted. A KMO value needs to be higher than 0.7 in order to be at least "middling" sampling adequate, while a KMO value of 1 represents perfect sampling adequacy ${ }^{11}$ (Kim and Mueller 1978, p. 54). In addition, the Bartlett's test of sphericity (BTS) indicates the significant confidence level regarding the coherence of factors and hence the reproducibility and generalisability of the results (Dziuban and Shirkey 1974; Kaiser 1974; Kim and Mueller 1978; Rummel 1970). The Kaiser criterion (Kaiser 1960) for the number of factors extracted is applied in this context. Thus a factor is disregarded unless it can explain the variance of at least one variable (eigenvalue higher than 1 ).

Furthermore, for robust explanatory power, we stipulate that the extracted factors explain at least $50 \%$ of the total cumulative variance. The oblique rotation is selected as it represents exploratory factoring more accurately than orthogonal rotation methods which are preferred when confirming models. To maintain statistical significance, variables with less than 0.55 coefficient loading (equal to $30.25 \%$ of the variance accounted for by the factor) are suppressed. Cut-off criteria for factor loadings remain a matter of debate (Bowles 2006; Conway and Huffcutt 2003; Cudeck and O'Dell 1994). Hair et al. (1998) suggest that the factor loading can be smaller the larger the sample size and the larger the number of variables being analysed; and that the larger the number of factors, the larger should be the size of the loadings to maintain statistical significance. Shapiro et al. (2002) indicate several factor coefficient loading cut-offs. ${ }^{12}$ Heuristics suggest that loadings higher than 0.30 are salient, and that cut-off selection between 0.30 and 0.60 (Bagozzi and Yi 1998; Swisher et al. 2004) is representative of factor analysis in empirical social science literature. Regarding the factor names, they are assigned based on the factor loading of the variables taking the higher loading variables into consideration, that is, variables that are most influenced by the underlying factor. Factor loadings point out the correlation between factors and variables, namely the extent to which the factors influence the variables, or phrased differently, the percentage of variation accounted for by factors.

The analysis of the survey data is structured as follows: initially, the latent factors to barriers to innovation are examined looking at all respondents; further, the respondents' answers are analysed separately since different actors assess the barriers to innovation differently, although there are commonalities. ${ }^{13}$ Results are reported at a statistically significant confidence level of $99 \%$. Factors influencing groups of variables 
with Cronbach's alpha below 0.7 are deemed inconsistent and unreliable. They are therefore rejected for policy purposes of drawing out lessons for other countries since Cronbach's alpha indicates the internal consistency and reliability of the factor and hence the cohesion of variables as a group. ${ }^{14}$

\section{Results and discussion of the main barriers to innovation}

We present the results of the factor analysis for all respondents as well as for the different groups of actors in the GNSI. Where appropriate comparisons and contrasts between all, and individual, actors are offered. It is important to note from the outset that the internal consistency of the factor barriers to innovation, represented by Cronbach's alpha, is high. Out of 16 Cronbach's alpha, only two are below 0.6 at 0.598 and 0.532 which are deemed "questionable". All others (87.5\%) are above 0.7 which is deemed "acceptable". The reliability of our factor analysis is therefore robust.

In the assessment of all respondents, four statistically significant factors influence the barriers to innovation. These are presented in Table 2. Factor 1, "skills-ICT capability/ capacity", the highest barrier to innovation in the GNSI, accounts for $33.524 \%$ of the total variance explained (TVE) and is responsible for $63.52 \%$ of the variance of the first variable "quality of technically trained manpower" and $61.62 \%$ of "rate of access" to ICT. This reflects the level, and uneven distribution, of skills and ICT resources in Ghana and generally within developing countries (Dutta and Bilbao-Osorio 2012). Even though Ghana has made efforts to bridge the digital divide (Koria et al. 2012), ICT infrastructure, such as internet access, storage capacity and processing capability, needs to be prioritised in government budgetary expenditures, since economy-wide innovativeness and innovation is extremely difficult to attain without threshold levels in skills and ICT capability and capacity.

Factors 2, 3 and 4, which are "unsophisticated markets", "deficient fiscal policy" and "Reduced Organisational Risks' respectively, also represent significant barriers to innovation. Markets are not sophisticated due to the lack of demanding and innovative consumers. Taken together, these factors point to a vicious cycle. The government is relatively ineffective in setting the right policy, incentives or competition environment for firms to reduce organisational risks and increase their productivity, consumers do not demand innovative products, and hence firms tend not to invest in R\&D and product development. ${ }^{15}$

Factors influencing barriers to innovation are presented in Table 3 for government respondents. 'Constrained Human Capital Resources' represents the highest barrier to innovation in the GNSI from the Government's perspective. Threshold levels of human and capital resources are crucial as they form the basis of innovation and development and, if the economy lacks high quality technically trained manpower in sufficient numbers or trained manpower in general, the opportunities for innovativeness and processes to be more efficient and effective are truncated. Factor 1 in all respondents is responsible for $63.5 \%$ of the variance in "quality of technically trained manpower", while in government respondents it accounts for $76.2 \%$. In order to improve the quality of manpower, explicit policies oriented to funding the development of skills-ICT capability and capacity should be promulgated and reinforced. For government, as for all respondents, "unsophisticated markets" is the second highest barrier to innovation accounting for $14.152 \%$ of TVE and influences the policy variables "lack of demanding 
Table 2 Latent factors to barriers to innovation (all respondents)

\begin{tabular}{|c|c|c|c|c|c|c|c|c|c|}
\hline \multirow[t]{2}{*}{ Factor Number } & \multirow[t]{2}{*}{ Name of Factor } & \multirow[t]{2}{*}{ Variables } & \multirow[t]{2}{*}{ Factor Loading } & \multirow[t]{2}{*}{ Cronbach's Alpha } & \multirow[t]{2}{*}{ Total Varience Explained } & \multirow[t]{2}{*}{ KMO } & \multicolumn{3}{|c|}{ Bartlets Test of Sphericity } \\
\hline & & & & & & & $\begin{array}{l}\text { Chi } \\
\text { Squared }\end{array}$ & Df & Significance \\
\hline \multirow[t]{4}{*}{1} & \multirow{4}{*}{$\begin{array}{l}\text { Skills-ICT Capability / } \\
\text { Capacity }\end{array}$} & * Quality of Technically Trained Manpower & 0.797 & \multirow[t]{4}{*}{0.833} & \multirow[t]{4}{*}{33.524} & \multirow[t]{13}{*}{0.817} & \multirow[t]{13}{*}{$1,625.579$} & \multirow[t]{13}{*}{136} & \multirow[t]{13}{*}{0.000} \\
\hline & & * Rate of Access to ICT & 0.785 & & & & & & \\
\hline & & * ICT Capacity & 0.760 & & & & & & \\
\hline & & * Lack of Technically Trained Manpower & 0.695 & & & & & & \\
\hline \multirow[t]{3}{*}{2} & \multirow[t]{3}{*}{ Unsophisticated Markets* } & * Lack of Demanding Customers & 0.892 & \multirow[t]{3}{*}{0.752} & \multirow[t]{3}{*}{9.671} & & & & \\
\hline & & * Lack of Innovative Customers & 0.839 & & & & & & \\
\hline & & * Lack of Competition & 0.682 & & & & & & \\
\hline \multirow[t]{2}{*}{3} & \multirow[t]{2}{*}{ Deficient Fiscal Policy } & * Lack of Finance & 0.770 & \multirow[t]{2}{*}{0.598} & \multirow[t]{2}{*}{8.437} & & & & \\
\hline & & * Lack of Explicit Policy Support & 0.737 & & & & & & \\
\hline \multirow[t]{4}{*}{4} & \multirow[t]{4}{*}{ Reduced Organisational Risks } & * Excessive Percieved Economic Risk & -0.809 & \multirow[t]{3}{*}{0.757} & \multirow[t]{3}{*}{7.037} & & & & \\
\hline & & * Organisational Rigidities & -0.723 & & & & & & \\
\hline & & * Hierachical Organisations & -0.675 & & & & & & \\
\hline & & $\begin{array}{l}\text { * Restrictive Public / Governmental } \\
\text { Regulations }\end{array}$ & -0.653 & Cumulative Total (CTVE) & 58.669 & & & & \\
\hline
\end{tabular}

NB. Residuals are computed between observed and reproduced correlations. There are 68 (50.0\%) non-redundant residuals with absolute values greater than 0.05 
Table 3 Latent factors to barriers to innovation (government)

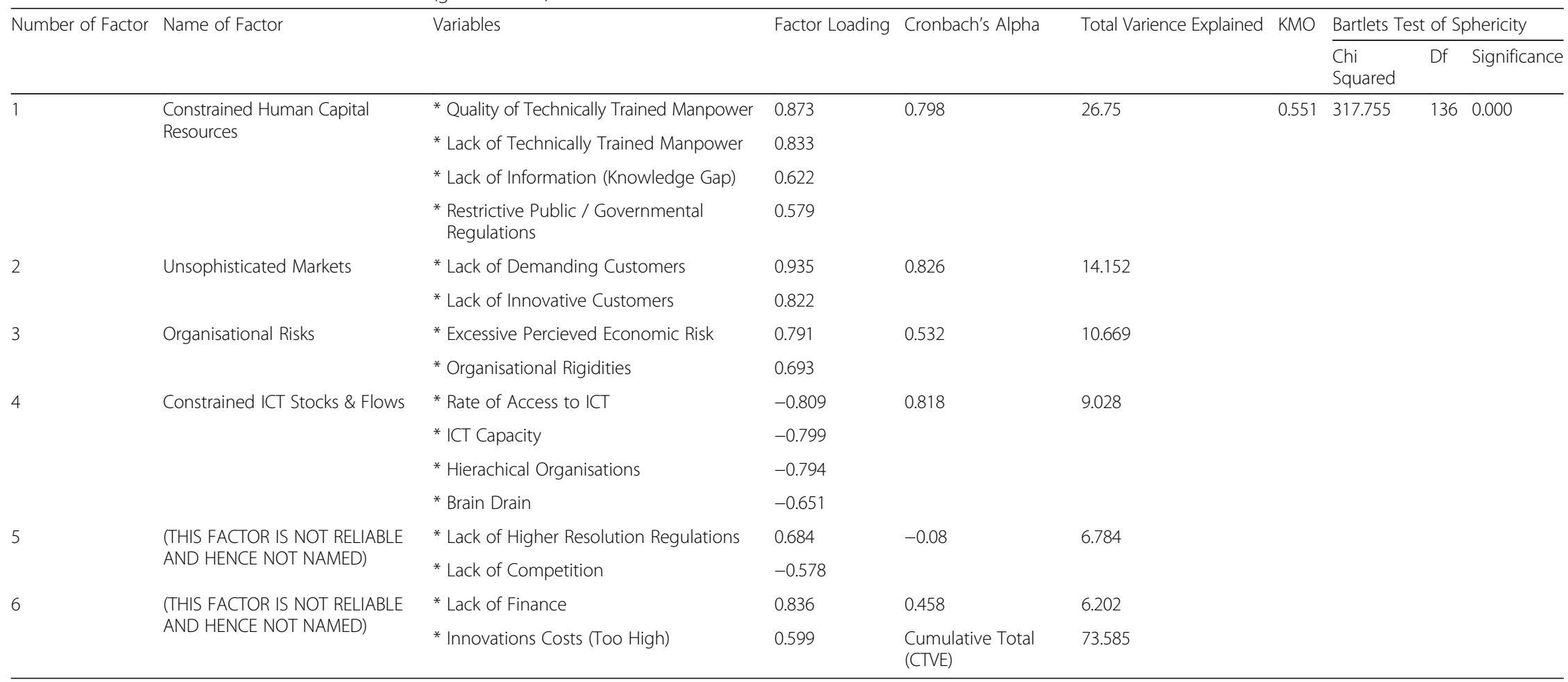

NB. Residuals are computed between observed and reproduced correlations. There are $66(48.0 \%)$ non-redundant residuals with absolute values greater than 0.05 
customers" and "lack of innovative customers" accounting for 87.4 and $67.6 \%$ of variance in these variables, respectively.

Factor 3 "organisational risks" is the third highest barrier to innovation which accounts for $10.669 \%$ of TVE. This reflects the need for the business and work environment not to be constrained either by organisational rigidities, such as long procedures, bureaucracy and high transaction costs, or by excessive perceived economic risk. Without the ease of doing business, economic agents are not confident sufficiently to approach either change or competition. This invokes the policy response of reducing economy-wide transaction costs. According to the World Bank Doing Business 2015, the average rankings of Sub-Saharan Africa (SSA) indicate "weaker legal institutions and more complex and expensive regulatory processes" (The World Bank and International Finance Corporation 2013, p. 4), and Ghana's average rank is 64 out of 185 countries. However, this average conceals widely dispersed indices in the regulatory environment that determine transaction costs.

Finally, factor 4 "constrained ICT flows and stocks" although a significant barrier accounts only for $9.028 \%$ of the TVE. Overcoming this barrier requires economy-wide infrastructure policy decisions to make available widely Internet broadband capacity so that Ghana can move towards an e-economy.

Table 4 presents the assessment of MHTI respondents. Analysing the MHTI perspective, the main barrier to innovation in the GNSI is "organisational risks" (it accounts for $40.52 \%$ TVE) in which the "excessive perceived economic risk" is the most crucial variable, since the factor is responsible of $63 \%$ of its variance. Firms are constrained from innovating in Ghana. As in most developing countries, firms cannot price risk adequately and hence lack the incentive to take new initiatives or start new businesses at a sufficiently elevated pace as this appears economically risky especially given unsophisticated markets that do not demand innovative products and services (Aubert 2005; Ernst 2000). Moreover, firms are not supported adequately by the fiscal, monetary, regulatory and standard policies designed by the government. ${ }^{16}$ The government and industry therefore need to engage in dialogue to align priorities through targeted policy.

Factor 2 "deficient fiscal policy" is the second highest barrier to innovation accounting for $10.759 \%$ of TVE. This is an extremely crucial factor as policy and finance support, and the level of innovation costs, are essential in determining the rate and quality of innovation in firms and hence in the economy (Goh 2006; Smits and Kuhlmann 2004; Zagler and Dürnecker 2003). This is explained in the variables "lack of explicit policy support", "lack of finance" and high "innovation costs" which is influenced by factor 2 and is responsible for 73.4, 58.5 and $48.2 \%$ of the variation in these variables, respectively.

Factor 3 named "unsophisticated markets" is the third highest barrier to innovation accounting for 8.988 \% TVE. From the MHTI perspective, the variable "brain drain" is influenced by this factor. Factor 3 is responsible for $33.4 \%$ of variance in this variable. This shows the necessity, in resource-constrained circumstances, of the need for government policy to be calibrated suitably to attract human capital resources in order to prevent the more qualified and educated work force leaving the country. The brain drain is a phenomenon that SSA experiences annually and it represents a socio-economic class of innovators, early adopters and early majority who are 
Table 4 Latent factors to barriers to innovation (medium-and high-tech industry)

\begin{tabular}{|c|c|c|c|c|c|c|c|c|c|}
\hline \multirow[t]{2}{*}{ Number of Factor } & \multirow[t]{2}{*}{ Name of Factor } & \multirow[t]{2}{*}{ Variables } & \multirow[t]{2}{*}{ Factor Loading } & \multirow[t]{2}{*}{ Cronbach's Alpha } & \multirow[t]{2}{*}{ Total Varience Explained } & \multirow[t]{2}{*}{$\mathrm{KMO}$} & \multicolumn{3}{|c|}{ Bartlets Test of Sphericity } \\
\hline & & & & & & & $\begin{array}{l}\text { Chi } \\
\text { Squared }\end{array}$ & Df & Significance \\
\hline \multirow[t]{3}{*}{1} & \multirow[t]{3}{*}{ Organisational Risks* } & * Excessive Percieved Economic Risk & 0.794 & \multirow[t]{3}{*}{0.821} & \multirow[t]{3}{*}{40.52} & \multirow[t]{14}{*}{0.744} & \multirow[t]{14}{*}{633.823} & \multirow[t]{14}{*}{136} & \multirow[t]{14}{*}{0.000} \\
\hline & & * Hierachical Organisations & 0.670 & & & & & & \\
\hline & & ${ }^{*}$ Organisational Rigidities & 0.608 & & & & & & \\
\hline \multirow[t]{3}{*}{2} & \multirow[t]{3}{*}{ Deficient Fiscal Policy * } & * Lack of Explicit Policy Support & 0.857 & \multirow[t]{3}{*}{0.765} & \multirow[t]{3}{*}{10.759} & & & & \\
\hline & & ${ }^{*}$ Lack of Finance & 0.765 & & & & & & \\
\hline & & * Innovations Costs (Too High) & 0.694 & & & & & & \\
\hline \multirow[t]{4}{*}{3} & \multirow[t]{4}{*}{ Unsophisticated Markets * } & * Lack of Demanding Customers & 0.909 & \multirow[t]{4}{*}{0.764} & \multirow[t]{4}{*}{8.988} & & & & \\
\hline & & * Lack of Innovative Customers & 0.827 & & & & & & \\
\hline & & * Lack of Competition & 0.595 & & & & & & \\
\hline & & * Brain Drain & 0.578 & & & & & & \\
\hline \multirow[t]{4}{*}{4} & \multirow{4}{*}{$\begin{array}{l}\text { ICT Skills Incapacity / } \\
\text { Incapability }\end{array}$} & ${ }^{*}$ Rate of Access to ICT & -0.854 & \multirow[t]{3}{*}{0.852} & \multirow[t]{3}{*}{8.432} & & & & \\
\hline & & $\begin{array}{l}\text { * Quality of Technically Trained } \\
\text { Manpower }\end{array}$ & -0.776 & & & & & & \\
\hline & & * ICT Capacity & -0.752 & & & & & & \\
\hline & & * Lack of Technically Trained Manpower & -0.702 & $\begin{array}{l}\text { Cumulative Total } \\
\text { (CTVE) }\end{array}$ & 68.699 & & & & \\
\hline
\end{tabular}

NB. Residuals are computed between observed and reproduced correlations. There are 71 (52.0\%) non-redundant residuals with absolute values greater than 0.05 
overwhelmingly professionals, technicians and the highly skilled. According to Adepoju (2007), Ghana was a top ten source of migration of professionals to the UK with an outflow of some 21,500 professionals (1999-2001), especially related to science, such as medical officers, dentists, pharmacists and nursing/midwifery personnel. The "brain drain" is directly related to "lack of competition" through the absence of a professionally demanding group of consumers.

Factor 4, "skills-ICT incapacity/incapability", is a significant barrier to innovation but explains only $8.432 \%$ of the TVE. In order to enable enhanced logistics, distribution and transport, and hence accelerate the flows of goods, services and information within the economy, it is necessary to upgrade the ICT network capacity and the related skills capability that represent the "central nervous system" of the economy.

The perspective on factor barrier to innovation in the GNSI provided by KBIs is presented in Table 5.

The highest factor barrier to innovation from the KBI perspective is represented by factor 1 "poor human capital", in which "lack of technically trained manpower" and "quality of technically trained manpower" are the most crucial variables. Factor 1 accounts for $32.466 \%$ of TVE and is responsible for 71.6 and $61.8 \%$ of the variance in the two respective variables. As mentioned previously, without adequate thresholds of human capital, the level of innovativeness and rate of innovation in the economy are likely to be severely debilitated and therefore inadequate to close the gap with the median middle-income countries.

Factor 2, "sophisticated markets", the second highest barrier to innovation accounting for $9.579 \%$ of TVE, influences the policy variables "lack of demanding customers", "lack of innovative customers" and "lack of competition" and accounts negatively for 81.2, 71.6 and $34.2 \%$ of variance in the variables, respectively. Innovative customers are decisive for stimulating companies to innovate and develop new process, new products and patents (Porter 1990; Robertson and Yu 2001).

Factor 3 "organisational risks" is the third highest barrier accounting for $8.579 \%$ of TVE and is responsible for 58.4, 55.4, 55.2 and $33.2 \%$ of the variance in "excessive perceived economic risk", "organisational rigidities", "restrictive public/governmental regulations" and "hierarchical organisations". Factor 4 is "ICT stocks and flows" but it accounts only $7.006 \%$ of the TVE.

In conclusion, the four main statistically significant factors explaining the highest part of TVE for all the respondents are skills-ICT capability/capacity, unsophisticated markets, deficient fiscal policy and reduced organisational risks. The four statistically significant factors for government are constrained human capital resources, unsophisticated markets, organisational risks and constrained ICT flows and stocks. Regarding MHTI, the four factors are organisational risks, deficient fiscal policy, unsophisticated markets and skills-ICT incapacity/incapability. Finally, factors for KBIs are poor human capital, sophisticated markets, organisational risks and ICT stocks and flows.

An overview of the factor barriers to innovation in the GNSI highlights four major recurrent policy dimensions that restrain innovation and prevent innovativeness in the Ghana economy. They are characterised as follows: the deficiencies in human capital skills related particularly to ICT capability and capacity could be considered as an "organisational capital" dimension (Hong et al. 2008; Vashishtha and Sharma 2011). The GNSI suffers from low concentrations of organisational capital which prevents system- 
Table 5 Latent factors to barriers to innovation (knowledge-based institutions)

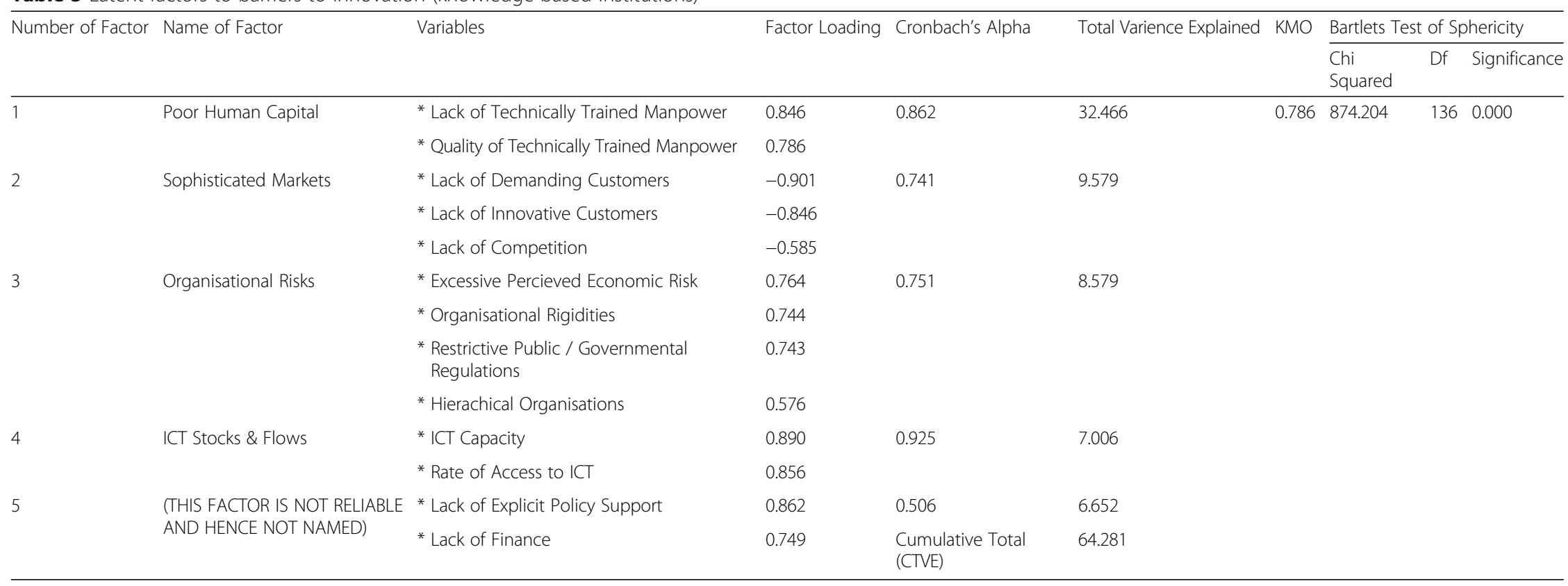

NB. Residuals are computed between observed and reproduced correlations. There are 60 (44.0\%) non-redundant residuals with absolute values greater than 0.05 
wide combinations of skills and assets for significant productivity enhancement based on science, technology, engineering, mathematics and information technology. The lack of innovating and demanding customers and the insufficiency in the level and quality of demand is the "market demand" dimension. This deficiency dissuades the manufacturing and service sectors from innovating in order to offer products of enhanced qualities and values. According to Porter (1990), in the absence of sufficient policy capacity and capability to influence the NSI competiveness, resource-constrained developing countries would be better off concentrating on ensuring that markets work properly with respect to increasing sophistication of supply and demand, industry rivalry and related and supporting industries. "Organisational constraints" is considered as the third dimension. This points to the investment risks perceived and managerial rigidities that throttle the adaptive response mechanisms in the behaviour of the GNSI actors, who are moreover prevented from responding adequately and competitively to market signals (Pech and Oakley 2005; Schumpeter 1947). The last dimension named "fiscal and monetary deficiencies" depicts financial shortfalls with respect to supporting risk in innovation in general and innovative processes specifically in the early stages of ideation, invention and start-up and launch of new businesses.

The main features of GNSI are the following: the asymmetry in density and distribution of actor inter-linkages; lack of sufficient levels of strategic coherence, organisational performance and externalities; the largely unresponsive Ghana economy to supply- and demand-side signals; and systematical rigidity and inflexibility in the face of changing conditions (Bartels and Koria 2012). Therefore, the Ghana government's intent to transform its "factor-driven" economic model into "innovation-driven" industrial development to deliver high levels of productivity, through enhancing competiveness, employment and equitable social and economic development, confronts major hurdles. Relatively high barriers to innovation aligned with poorly configured and inadequately calibrated policy instruments imply incompatibilities in the GNSI that have to be tackled economy- and system-wide, as well as at the level of actor-specific interventions.

Our elaboration of the standard Triple Helix to a type 4, as indicated in Fig. 1, serves to identify statistically significant barriers to innovation, ${ }^{17}$ in terms of the factors that interrupt the intra-, inter-relations within, and between, the core actions in the NSI. We aver that, given the myriad complexities in the different varieties of "capital"18 which, in concert, drive socio-economic development and wealth creation (Svendsen and Svendsen 2003), to consider NSI without reference to the explicit role of arbitrageurs and ICT is to miss out on valuable instrumentation for policy making. We argue that our type 4 Triple Helix model of NSI enables a deeper understanding of the relationships between innovation-driven economic growth and institutional dimensions (both formal and informal) of wealth creation.

Our finding that the highest barrier to innovation and innovativeness is deficient organisational capital manifest as the factor skills-ICT capability/capacity, which in turn influences the variables of human capital resources and ICT, is supported by Stenholm et al. (2013). They find, in a cross-country analysis of 63 countries, regarding entrepreneurial activity (i.e. innovation and innovativeness) that, significantly, the type of entrepreneurial activity is determined by the "conducive" factor which influences the following variables: ICT; university-industry collaboration; 
venture capital; and available technology. These variables are central to our type 4 Triple Helix model for NSI.

In developing countries, barriers to innovation, expressed as the relatively poor effectiveness and low efficiency of the NSI, are manifest in largely absent ICT, truncated linkages between core actors, extremely thin arbitrageur (venture capital) intermediation and inadequate technologically competent human capital.

\section{Policy recommendations and concluding remarks}

With a management of innovation policy and pragmatic perspective, we now address the policy recommendations appropriate to the dimensions of identified barriers to innovation previously discussed and draw lessons for developing countries. Ghana shares many characteristics of development, with respect to innovation, with other developing countries. ${ }^{19}$ Policy recommendations to address deficiencies in "organisational capital" refer to the central role played concertedly by education, enterprise and management. This role, firstly, should be characterised by curricula reform that is recalibrated to the needs of MHTI. Secondly, by secondary and tertiary education, vocational training and specific enterprise-based training reoriented towards an increasing emphasis on science, technology, engineering, mathematics and information technology. Moreover, it is necessary to create an educational network between KBIs and MHTI to ensure knowledge transfer and the spread of new ideas thereby creating a work environment that is much more challenging and stimulating and thus able to mitigate the brain drain. Clearly, ICT needs to be included through the upgrade of the information systems infrastructure in order to enable ICT diffusion and the reduction of ICT network costs. However, given the nature of ICT (Chinn and Fairlie 2004; van Disk and Hacker 2003), this is a long-term policy dynamic. For example, India laid the foundations for its present excellence in providing out-sourced services in ICT and software-related industries in the 1950s and 1960s through the establishment of institutes of technology (Mann et al. 2000; Piazolo 2001).

Policy recommendations to address insufficiencies in "market demand" include, firstly, the introduction, and improvement, of standards-based regulation and performance requirements to stimulate firms to be more adaptive technologically. Secondly, in order to cultivate a dynamic innovation environment, incentives for commercialisation of publicly funded R\&D at KBIs should be strengthened and the patent management of the intellectual property rights (IPRs) needs to be improved. According to the International Property Rights Index $2015,{ }^{20}$ Africa ranks seventh (out of seven), the lowest, for intellectual property rights. Ghana ranks 50th (out of 129). Without the protection of law, intellectual assets-the wellspring of ideation, invention and innovation-and innovativeness can neither be exploited effectively nor efficiently because collateralisation is virtually impossible.

In the policy recommendations to address "organisational constraints", attention should be on the bureaucracy and procedures. This consist, for example, of reducing the number of processes, the length of time and the cost to start a business; eliminating bottlenecks in grating permits and securing access to energy; speeding up the procedures to register property; recalibrating the tax regime to reward entrepreneurship (Aubert 2005); and reducing barriers to cross border trade in terms of documentation and licences. Developing countries, especially those in Sub-Saharan Africa, face serious hurdles in these areas. ${ }^{21}$ 
Finally, the policy recommendations to address "fiscal and monetary deficiencies" in the GNSI focus more on the alignment of funding, fiscal and monetary, support of performance and the development of monitoring and audit instruments. For example regarding domestic credit provided by the banking sector (percentage of GDP 2012), Sub-Saharan African countries range from -8.9 (Congo Republic) to $187.2 \%$ (South Africa) with most below $50 \%{ }^{22}$

\section{Implications for developing countries}

The dimensional barriers to innovation in Ghana-lack of organisational capital, insufficient market demand, organisational constraints and fiscal and monetary deficiencie$\mathrm{s}$-are prevalent in developing countries and particularly in Sub-Saharan Africa. These are manifest at different levels of intensity, with differing nuances, across the heterogeneity of developing countries.

Across developing countries, these dimensions could be distilled into two primary interrelated constraining vectors that hinder innovation: the institutional, on the one hand (Rodrik et al. 2004; Trebilcock 1996; Trebilcock and Prado 2011); and on the other hand, the financial (Alfaro et al. 2008; Gorodnichenko and Schnitzer 2010). Indeed, it is this twin deficiency that defines developing countries and places them in the low-income divide compared to high-income countries (Durlauf and Quah 1999). The vectors are related in that, answering the question why capital does not flow from rich to poor countries, Alfaro et al. (2008, p. iii) conclude that "low institutional qual$i^{2}{ }^{23}$ is the leading explanation for lack of capital flows". Furthermore, "financial constraints restrain the ability of domestically owned firms to innovate and export and hence to catch up to the technological frontiers" (Gorodnichenko and Schnitzer 2010, p. iii). It is noticeable that total factor productivity differences between developed and developing countries are larger in machinery and equipment (Herrendorf and Valentinyi 2012). Aggregating these two vectors further, non-material forms of capital such as social capital explain differences in economic growth (Svendsen and Svendsen 2003) and Olson (1996, p. 19) indicates that "the only remaining plausible explanation is that the great differences in the wealth of nations are mainly due to differences in the quality of their institutions and economic policies".

Ghana, and other developing countries, would need to pay concerted attention to ensuring that their institutional architecture, which gives rise to organisational capital and market demand, functions coherently and serves the interests of society as a whole. Policy prescriptions are not in short supply in this area (Bartels 2007; Bartels and Koria 2012; Birdsall et al. 2005) with respect to institutional quality and requisite investments in social stabilisers, law and order and non-corruption. Developing countries also would need to spend their limited financial resources wisely. ${ }^{24}$ It is cogent to revisit Bauer (1981, p. 248) regarding economic development requiring "charges in attitudes and mores adverse to material improvement... and the pursuit of appropriate government policies".

In conclusion, this paper has sought to fill the gap in the empirical and analytical measurement of NSI by providing a significant factor analytic view of the barriers to innovation in the GNSI with respect to the type 4 Triple Helix actors. The statistically significant latent factors underpinning the barriers to innovation are identified by four main dimensions as skills, markets, finances and risks. These results enable policy 
makers to fix achievable targets and standards to stimulate firms and industry to be more productive and to create a better environment for all actors to innovate.

\section{Endnotes}

${ }^{1}$ An early exception in 1993 is the edited book by Richard R. Nelson National Innovation Systems: A Comparative Analysis, which includes descriptive NSI analysis of European states as well as of selected states from Latin America.

${ }^{2}$ These two expressions are considered interchangeable and both are found throughout the literature (see Fagerberg and Srholec 2008; Lundvall 1995; Nasierowski and Arcelus 1999; Niosi et al. 1993).

${ }^{3}$ See African Union Summit (2007) on science and technology for Africa's development.

${ }^{4}$ The 35 DRUID Celebration Conference 2013, 17-19 Jun, ESADE Business School, Ramon Llull University, Barcelona.

${ }^{5}$ Triple Helix International Conference 2013, 8-10 July, University of London, United Kingdom.

${ }^{6}$ See Tidd (2006, p. 10), Fig. 1, for elucidation of the different types of innovation networks between firms.

${ }^{7}$ Based on 2012 figures-global innovation index.

${ }^{8}$ Based on 2013 figures-global innovation index.

${ }^{9}$ See Bartels et al. (2009, p. 14) and Bartels et al. (2013) for elucidation.

${ }^{10} 1$ - very high constraint to 5 - very low constraint. The instrument was subjected to peer review by Prof. J. Howells (Centre for Research on Innovation and Competition, UK) and Prof. S. Mani (Centre for Development Studies, India).

${ }^{11} \mathrm{KMO}$ values higher than 0.9 represents "marvellous" sampling adequacy; a value between 0.8 and 0.9 represents "meritorious" sampling adequacy; between 0.7 and 0.8 represents "middling" sampling adequacy; the range between 0.6 and 0.7 represents "mediocre" sampling adequacy, while that including 0.5 and 0.6 represents "miserable" sampling adequacy; and values less than 0.5 represents "unacceptable" sampling adequacy.

${ }^{12}$ These range from $\geq 0.400$ to $\geq 0.600$.

${ }^{13}$ The sample of arbitrageurs is adequate as a significant fraction of the universe of arbitrageurs in Ghana. However, the absolute number does not meet the statistical requirements for performing exploratory factor analysis.

${ }^{14}$ Cronbach's $\alpha \geq 0.9$ "Excellent"; $0.9>\alpha \geq 0.8$ "Good"; $0.8>\alpha \geq 0.7$ "Acceptable"; $0.7>\alpha \geq 0.6$ "Questionable"; $0.6>\alpha \geq 0.5$ "Poor"; $\alpha<0.5$ "Unacceptable". See Bartels and Koria (2012, p. 46, Table 9.6) and Cortina (1993).

${ }^{15}$ Ghana's R\&D expenditure is approximately $0.3 \%$ of GDP (US\$49 million), almost all from government provision (UNCTAD, 2011, Science, Technology and Innovation Policy Review-Ghana, Geneva).

${ }^{16}$ The available policy instruments are assessed by the actors in the GNSI as unsuccessful with respect to barriers to innovation (see Bartels and Koria 2012 for detailed analysis).

${ }^{17}$ Our current research into the model extends to deploying regression techniques to compare the effectiveness and efficiency of the NSI of Ghana and Kenya (IST Africa 
2014 Conference, 6-9 May 2014, Mauritius); as well as using structural equation modeling of the efficacy of the GNSI.

${ }^{18}$ Svendsen and Svendsen (2003, p. 608) refer to a "plethora of capitals" in Woolcock M (1998). Social capital and economic development: toward a theoretical synthesis and policy framework. Theory and Society 27(2): 151-208.

${ }^{19}$ It ranks 102th out of 189 countries for starting a business; 171th for trading across borders; 132th for dealing with construction permits and 161th for resolving insolvency according to the World Bank Doing Business rankings (http://www.doingbusiness.org/ rankings) of June 2015. From the 40 Sub-Saharan countries, 29 have rankings that are below 121 out of 189 for ease of doing business-a prerequisite for enabling innovativeness in the economy.

${ }^{20} \mathrm{http}$ ://internationalpropertyrightsindex.org/ accessed 27 May 2016.

${ }^{21}$ Out of 189 countries, with respect to registering property, paying taxes and getting electricity, respectively, there are only one (Rwanda), five (Mauritius, South Africa, Seychelles, Zambia and Rwanda) and one (Mauritius) African countries in the top 50 rankings (http://www.doingbusiness.org/rankings).

${ }^{22}$ World Bank data (data.worldbank.org/indicator/FS.DOMS.GD.ZS).

${ }^{23}$ The quality of institutions means the quality of contract enforcement, property rights and shareholder protection (Levchenko, 2007).

${ }^{24}$ According to nationmaster.com in the ranking of military expenditure per US\$ GDP, developing countries feature 7 of out the top 10 spenders; 14 out of the top 20 spenders; and 24 out of the top 30 spenders. SSA spends approximately US\$ 10 billion annually on the military. http://www.nationmaster.com/. Furthermore, according to the Stockholm International Peace Research Institute, SSA spent US\$20.4 billion on military expenditure; Asia and Oceania US\$ 364 billion; and South America US\$ 66 billion. https://www.sipri.org.

\section{Additional file}

Additional file 1: Translation of the abstract into Arabic. (PDF $322 \mathrm{~kb}$ )

Received: 4 October 2015 Accepted: 6 October 2016

Published online: 04 November 2016

References

Abramovitz M (1986) Catching up, forging ahead, and falling behind. J Econ Hist 46:385-406. doi:10.1017/S0022050700046209

Achim IM, Popescu T (2009) The systemic approach to national innovation systems in a knowledge-based economy. Annales Universitatis Apulensis: Series Oeconomica 11: 946-952

Adams J, Bessan J, Phelps R (2006) Innovation management measurement: a review. Int J Manag Rev 8:21-47. doi:10.1111/j.1468-2370.2006.00119.x

Adepoju A (2007) Migration in Sub-Saharan Africa. Background paper commissioned by the Nordic Africa Institute for the Swedish Government White Paper on Africa. Lagos: Human Resources Development Centre

African Union Summit (2007) Science technology and scientific research and climate change: Africa Union-Economic Commission for Africa, Science and Innovation Exhibition. Addis Ababa, Ethiopia, 22-30 January

Albuquerque EDM (1999) National systems of innovation and non-OECD countries: notes about a rudimentary and tentative "typology". Braz J Polit Econ 19:35-52

Albuquerque E, Suzigan W, Kruss G, Lee K. (eds) (2015) Developing National Systems of Innovation: university industry interactions in the Global South. Edward Elgar Publishing, Cheltenham

Alfaro L, Kalemli-Ozcan S, Volosovych V (2008) Why doesn't capital flow from rich to poor countries? An empirical investigation. Rev Econ Stat 90:347-368. doi:10.1162/rest.90.2.347

Amin A, Cohendet O (2005) Geographies of knowledge formation in firms. Ind Innov 12:465-486. doi:10.1080/13662710 500381658

Andersson M, Karlsson C (2004) Regional innovation systems in small \& medium- sized regional: a critical review and assessment. Electronic Working Paper Series, Paper No. 10, JIBS, CESIS 
Archibugi D, lammarino S (1999) The policy implications of the globalization of innovation. Res Policy 28:317-336. doi:10.1016/S0048-7333(98)00116-4

Arnold E (2004) Evaluating research and innovation policy: a system world needs systems evaluations. Res Eval 13:3-17. doi:10.3152/147154404781776509

Arnold E (2011) Synthesis Report. International audit of research, development and innovation in the Czech Republic.

Arocena R, Sutz J (2000a) Looking at national systems of innovation from the south. Ind Innov 7:55-75. doi:10.1080/713670247

Arocena R, Sutz J, (2000b) Interactive learning and development policies in Latin America. DURID Summer Conference on the Learning Economy. Rebild, Denmark, 15-17 June

Asheim BT, Coenen L (2004) The role of regional innovation systems in a globalising economy: comparing knowledge bases and institutional frameworks of Nordic clusters. DRUID Summer Conference, 14-16 June

Asheim BT, Gertler MS (2005) The geography of innovation: regional innovation systems. Oxford University Press, Oxford

Asheim B, Iskasen A (2002) Regional innovation systems: the integration of local sticky and global ubiquitous knowledge. J Technol Transf 27:77-86. doi:10.1023/A:1013100704794TI

Aubert JE (2005) Promoting innovation in developing countries: a conceptual framework. World Bank Policy Research Working Paper No. 3554

Bagozzi RP, Yi Y (1998) On the evolution of structural equation models. Acad Market Sci 16:74-94. doi:10.1007/ BF02723327

Bartels FL (2007) Industry in growth and development: a review of contending development policy advisory directions. UNIDO Working Paper No 01/2001. UNIDO Research and Statistics Branch Staff, Vienna, Austria

Bartels FL, Koria R (2012) Evidence-based policy making. The Ghana national system of innovation-measurement, analysis \& policy recommendations. GNSI Report 2012. UNIDO, Vienna, Austria

Bartels FL, Koria R (2013) Low carbon development: the challenges of 'green' innovation. Paper presented at Globalics Seminar on Learning, Innovation and Low Carbon Development, Report of the Globalics Seminar on Learning, Innovation and Low Carbon Development, Copenhagen, Denmark, 4-5 April

Bartels FL, Lederer S (2009) Changing patterns in industrial performance-a UNIDO competitive industria performance perspective: implications for industrial development. UNIDO Working Paper No 05/2009. UNIDO, Vienna, Austria

Bartels FL, Voss H (2005) Determinants of national innovation systems. Paper presented at the 14th International Conference for the International Association of Management of Technology, Vienna, Austria

Bartels FL, Koria R, Carneiro S (2009) National systems of innovation in selected emerging market economies: an examination of actors, interactions and constraints. Euro-Asia management studies association (EAMSA)

Bartels FL, Voss H, Lederer S, Bachtrog C (2012) Determinants of national innovation systems: policy implications for developing countries. Innov Manag Policy Pract 14:2-18. doi:10.5172/impp.2012.14.1.2

Bartels FL, Koria R, Andriano L (2013) Determinants of innovativeness in the Ghana National System of Innovation (GNSI): policy implications for middle-income developing countries. Res Policy, under review

Bauer P (1981) Equality, the Third World, and economic delusion. Harvard University Press, Cambridge

Becheikh N, Landry R, Amara N (2006) Lessons from innovation empirical studies in the manufacturing sector: a systematic review of the literature from 1993-2003. Technovation 26:644-664. doi:10.1016/j.technovation. 2005.06.016

Bell M (2002) Knowledge resources, innovation capabilities and sustained competitiveness in Thailand: transforming policy processes. Report of the project "Thailand: National Science and Technology Policy Capacity". SPRU, Sussex University. Mimeo

Birdsall N, Rodrik D, Subramaniam A (2005) How to help poor countries. Foreign Aff 84:136-152

Bjørnskov C, Svendsen GT (2002) Why does the northern light shine so brightly? Decentralisation, social capital and the economy. Aarhus School of Business, Working Paper 15

Blanc H, Sierra C (1999) The internationalization of R\&D by multinationals: a trade-off between external and internal proximity. Camb J Econ 23:187-206. doi:10.1093/cje/23.2.187

Bleda M, Del Rio P (2013) The market failure and the systemic failure rationales in technological innovation systems Res Policy 42(5):1039-1052

Bowles TV (2006) The adaptive change model: an advance on the transtheoretical model of change. J Psychol 140:439457. doi:10.3200/JRLP.140.5.439-457

Buckley PJ, Carter MJ (2004) A formal analysis of knowledge combination in multinational enterprises. J Int Bus Stud 35: 371-384. doi:10.1057/palgrave.jibs.8400095

Bugge MM, Mortensen PS, Bloch C (2011) Measuring public innovation in Nordic countries. Nordisk Institutt for Studier av Innovasjon, Forskning og Utdanning, Rapport 40/2011

Bush V (1945) Science-the endless frontier. United States Government Printing Office, Washington DC

Cai Y (2011) Factors affecting the efficiency of the BRICSs' national innovation systems: a comparative study based on DEA and panel data analysis. Discussion paper No 2011-52. http://www.economics-ejournal.org/economics/ discussionpapers/2011-52. Accessed 13 Oct 2016

Carlisle Y, McMillan E (2006) Innovation in organizations from a complex adaptive systems perspective. Emergence: Complexity and Organization 8: 2-9

Carlsson B (2006) Internationalization of innovation system: a survey of literature. Res Policy 35:56-67. doi:10.1016/j. respol.2005.08.003

Carlsson B, Stankiewicz R (1991) On the nature, function and composition of technological systems. J Evol Econ 1:93118. doi:10.1007/BF01224915

Chaminade C, Intarakumnerd P, Sapprasert K (2008) Measuring systemic failures in innovation systems in developing countries using innovation survey data: The case of Thailand

Chaminade C, Intarakumnerd P, Sapprasert K (2012) Measuring systemic problems in national innovation systems. An application to Thailand. Res Policy 41:1476-1488. doi:10.1016/j.respol.2012.04.004 
Chang SH, Lin PH (2012) A preliminary study on the structural model of national innovation capability. J Int Manag Stud 7:128-137

Chinn MD, Fairlie RW (2004) The determinants of the global digital divide: a cross-country analysis of computer and internet penetration. IZA, Discussion paper series, No. 1305

Cohen WM, Nelson RR, Walsh JP (2000) Protecting their intellectual assets: appropriability conditions and why U.S. Manufacturing firms patent (or not). NBER Working Paper No. 7552. NBER, Cambridge, MA

Conway JM, Huffcutt Al (2003) A review and evaluation of exploratory factor analysis practices in organisational research. Organ Res Methods 6:147-168. doi:10.1177/1094428103251541

Cooke P (2002) Biotechnology clusters as regional, sectoral innovation systems. Int Reg Sci Rev 25:8-37. doi:10.1177/ 016001760202500102

Cooke P, Leydesdorff L (2006) Regional development in the knowledge-based economy: the construction of advantage. J Technol Transfer 31:5-15. doi:10.1007/s10961-005-5009-3

Cooke P, Morgan K (1999) The associational economy: firms, regions, and innovation. Oxford University Press, Oxford

Cortina JM (1993) What is coefficient alpha? An examination of theory and applications. J Appl Psychol 78:98-104. doi:10.1037/0021-9010.78.1.98

Cudeck R, O'Dell LL (1994) Applications of standard error estimates in unrestricted factor analysis: significance tests for factor loadings and correlations. Psychol Bull 115:475-487. doi:10.1037/0033-2909.115.3.475

Davis KE, Ekboir J, Spielman DJ (2008) Strengthening agricultural education and training in sub-Saharan Africa from an innovation systems perspective: a case study of Mozambique. J Agric Educ Ext 14(1):35-51

Delgado M, Ketels C, Porter ME, Stern S (2012) The determinants of national competitiveness. NBER Working Paper Series No. 18249

Di Stefano G, Gambardella A, Verona G (2012) Technology push and demand pull perspectives innovation studies: current findings and future research directions. Res Policy 41:1283-1295. doi:10.1016/j.respol.2012.03.021

Do Navarro M, Gibaja JJ (2009) Typologies of innovation based on statistical analysis for European and Spanish Regions. Basque Institute of Competitiveness Working Papers Innova 2009-4- University of Deusto-ESTE, San Sebastian

Dodgson M, Hughes A, Foster J, Metcalfe S (2011) Systems thinking, market failure, and the development of innovation policy: the case of Australia. Res Policy 40(9):1145-1156

DRUID (1999) Conference on national innovation systems, industrial dynamics and innovation policy. Rebild, Denmark, 9-12 June

DRUID (2012) Conference on innovation and competitiveness: dynamics of organisations, industries, systems and regions. Copenhagen, Denmark, 19-21 June

Durlauf SN, Quah DT (1999) The new empirics of economic growth. Handb Macroecon 1:235-308. doi:10.1016/S15740048(99)01007-1

Dutta S, Bilbao-Osorio B (2012) The Global Information Technology Report 2012: living in a hyperconnected world. World Economic Forum, Geneva. doi:10: 92-95044-33-9

Dutta S, Lanvin B, Wunsch-Vincent S (2014) The Global Innovation Index 2014: the human factor in innovation. Fontainebleau, Ithaca, and Geneva

Dutta S, Lanvin B, Wunsch-Vincent S (2015) The Global Innovation Index 2015: effective innovation policies for development. Fontainebleau, Ithaca, and Geneva

Dziuban CD, Shirkey ES (1974) When is a correlation matrix appropriate for factor analysis? Some decision rules. Psychol Bull 81:358-361. doi:10.1037/h0036316

Economist Intelligence Unit (2012) Country Report Ghana http://country.eiu.com/ghana. Accessed 13 Oct 2016

Edquist C (1997) Systems of innovation approaches-their emergence and characteristics, in systems of innovation: technologies, institutions and organizations. Pinter, London

Edquist C (2005a) Systems of innovation approaches-their emergence and characteristics, in systems of innovation: technologies, institutions and organizations. Pinter, London

Edquist C (2005b) Systems of innovation: perspectives and challenges. In: Fagerberg J, Mowery DC, Nelson RR (eds) The Oxford Handbook of Innovation. Oxford University Press, Oxford

Edquist C (2010) Systems of innovation perspectives and challenges. Afr J Sci Technol Innov Dev 2:14-45

Edquist C, Lundvall BĂ (1993) Comparing Danish and Swedish systems of innovation. In: Edquist C (ed) Systems of innovation, technologies, institutions and organizations. Pinter, London

Ernst D (2000) Global production networks and the changing geography of innovation systems: implications for developing countries. East-west Center Working Papers: Economics Series, No. 9

Etzkowitz H (2002) Incubation of incubators: innovation as a Triple Helix of university-industry-government networks. Sci Public Policy 29:115-128. doi:10.3152/147154302781781056

Etzkowitz H, Leydesdorff $L$ (2000) The dynamics of innovation: from national systems and "mode 2" to a triple helix of university—industry—government relations. Res Policy 29:109-123. doi:10.1016/50048-7333(99)00055-4

European Research Council Expert Group (2003) A cornerstone in the European Research Area. Ministry of Science, Technology and Innovation. Copenhagen, Denmark

Everitt BS (2002) The Cambridge Dictionary of Statistics, 2nd edn. Cambridge University Press, Cambridge.

Fagerberg J (2005) Innovation: a guide to the literature. In: Fagerberg J, Mowery DC, Nelson RR (eds) The Oxford handbook of innovation. Oxford University Press, Oxford

Fagerberg J, Srholec M (2008) National innovation systems, capabilities and economic development. Res Policy 37: 1417-1435. doi:10.1016/j.respol.2008.06.003

Fagerberg J, Srholec M, Verspagen B (2010) Chapter 20-innovation and economic development. Handb Econ Innov 2:833-872

Fisher M, Revilla-Diaz J, Snickars F (2001) Metropolitan innovation system: theory and evidence from metropolitan regions in Europe. Springer, New York

Florida R (1995) Toward the learning region. Futures 27:527-536. doi:10.1016/0016-3287(95)00021-N

Florida R (2005) The world is spiky. Atl Mon 296:48-51

Freeman C (1987) Technology policy and economic performance: lessons from Japan. Pinter, London. 
Freeman C (2002) Continental, national and sub-national innovation systems-complementarity and economic growth. Res Policy 31:191-211. doi:10.1016/S0048-7333(01)00136-6

Gatignon H, Tushman ML, Smith W, Anderson P (2001) A structural approach to assessing innovation: construct development of innovation locus, type and characteristics. INSEAD Working Paper, November, 2001/97/MKT

Gatignon H, Tushman ML, Smith W, Anderson P (2002) A structural approach to assessing innovation: construct development of innovation locus, type and characteristics. INSEAD Working Paper, May, 2002/71/MKT

Gaur S (1997) Adelman and Morris factor analysis of developing countries. J Policy Model 19:407-415. doi:10.1016/S016 1-8938(96)00062-2

Geels FW (2004) From sectoral systems of innovation to socio-technical systems: Insights about dynamics and change from sociology and institutional theory. Res Policy 33:897-920. doi:10.1016/j.respol.2004.01.015

Goh ALS (2006) Evolution of industrial policy-making in support of innovation: the case of Singapore. Int J Innov Learn 3:110-125. doi:10.1504/IJLL.2006.008183

Gorodnichenko Y, Schnitzer M (2010) Financial constraints and innovation: why poor countries don't catch up. National Bureau of Economic Research, No. w15792

Hair FJ, Anderson RE, Tatham RL, Black WC (1998) Multivariate data analysis, 5th edn. Prentice Hall, New Jersey.

Harzing AW (2006) Response styles in cross-national survey research. A 26-country study. Int J Cross Cult Manag 6:243266. doi:10.1177/1470595806066332

Herrendorf B, Valentinyi A (2012) Which sectors make poor countries so unproductive? J Eur Econ Assoc 10:323-341. doi:10.1111/j.1542-4774.2011.01062.x

Hidalgo A, Albors J (2008) Innovation management techniques and tools: a review from theory and practice. R\&D Manag 38:113-127. doi:10.1111/j.1467-9310.2008.00503.x

Holland JH (1993) Innovation in complex adaptive systems: some mathematical sketches. SFI Woking Paper: 1993-10-062

Holland JH (2006) Studying complex systems. J Syst Sci Complex 19:1-8. doi:10.1007/s11424-006-0001-z

Hong PT, Plowman D, Hancock P (2008) The evolving research on intellectual capital. J Intellect Cap 9:585-608. doi:10.1108/14691930810913177

Howells J (2006) Intermediation and the role of intermediaries in innovation. Res Policy 35:715-728. doi:10.1016/j.respol. 2006.03.005

Intarakumnerd P, Chairatana P, Tangchitpiboon T (2002) National innovation system in less successful developing countries: the case of Thailand. Res Policy 31(8):1445-1457

Intrakumnerdi P, Chaminade C (2007) Innovation system policies in less successful developing countries: the case of Thailand. Centre for Innovation, Research and Competence in the Learning Economy (CIRCLE), Lund University, (2007/09).

Kaiser HF (1960) The application of electronic computers to factor analysis. Educ Psychol Meas 20:141-151. doi:10.1177/ 001316446002000116

Kaiser HF (1974) An index of factorial simplicity. Psychometrika 39:31-36. doi:10.1007/BF02291575

Kastelle T, Potts J, Dogson M (2009) The evolution of innovation systems. DRUID Summer Conference. Frederiksberg, Denmark, 17-19 June

Keynes JM (1936) The general theory of employment, interest and money. Macmillan, London

Kim JO, Mueller CW (1978) Factor analysis: statistical methods and practical issues. Sage 14

Koria R, Köszegi S (2011) National systems of innovation (NSI): Measurement and implications for science technology and innovation policy in Ghana: UNIDO conference on competitiveness and diversification: strategic challenges in a petroleum-rich economy. Accra, Ghana, 14-15 March

Koria R, Bartels FL, Koeszegi S, Carneiro S (2012) Free Open Source Software (FOSS) and survey methodologies: the case of the Ghana national system of innovation survey. Paper presented at the IST-Africa 2012 Conference Proceedings.

Koria R, Bartels FL, Köszegi S (2013) Surveying national systems of innovation (NSI) using free open source softwares (FOSS): the case of Ghana. Paper presented at the IST-Africa 2013 Conference Proceedings

Labovitz S (1967) Some observations on measurement and statistics. Soc Forces 46:151-160. doi:10.2307/2574595

Labovitz S (1970) The assignment of numbers to rank order categories. Am Sociol Rev 35:515-524. doi:10.2307/2092993

Labovitz S (1971) In defense of assigning numbers to ranks. Am Sociol Rev 26:521-522

Lane DA, Maxfield R (2004) Ontological uncertainty and innovation. SFI Working Paper 2004-06-014

Le Billon P, Good E (2015) Responding to the commodity bust: downturns, policies and poverty in extractive sector dependent countries. The Extractive Industries and Society

Levchenko AA (2007) Institutional quality and international trade. Rev Econ Stud 74(3):791-819

Levin S (2002) Complex adaptive systems: exploring the known, the unknown and the unknowable. B Am Math Soc 40:3-19. doi:10.1090/50273-0979-02-00965-5

Leydesdorff $L$ (2001) Knowledge-based innovation systems and the model of a Triple Helix of university-industrygovernment relations. Conference on new economic windows: paradigms for the new millennium. Salerno, Italy

Leydesdorff $L$ (2005) The Triple Helix model and the study of knowledge-based innovation systems. Int J Contemp Sociol 42:12-27

Leydesdorff L (2012) The Triple Helix, Quadruple Helix, and an n-tuple of helices: explanatory models for analyzing the knowledge-based economy? J Knowl Econ 3:25-35. doi:10.1007/s13132-011-0049-4

Leydesdorff L, Etzkowitz H (1996) Emergence of a Triple Helix university-industry-government networks. Sc Public Policy 23:279-286. doi:10.1093/spp/23.5.279

List F (1841) The national system of political economy. Longman, London

Lopes HF, West M (2004) Bayesian model assessment in factor analysis. Stat Sin 14:41-67

Lundvall $B \check{A}$ (1988) Innovation as an interactive process: from user-producer interaction to the national system of innovation. In: Dosi G, Freeman C, Nelson R, Silverberg G, Soete L (eds) Technical Change and Economic Theory (pp. 349-369). Pinter, London

Lundvall BĂ (1992) National systems of innovation: towards a theory of innovation and interactive learning. Printer, London

Lundvall BÅ (1995) National systems of innovation: towards a theory of innovation and interactive learning. Pinter, London 
Lundvall BÅ (2004) National innovation systems-analytical concept and development tool. DRUID 10th Anniversary Summer Conference. Copenhagen, Denmark, 27-29 June

Lundvall BÅ (2007) National innovation systems-analytical concept and development tool. Ind Innov 14:95-119. doi:10.1080/13662710601130863

Lundvall BÅ, Johnson B (1994) The learning economy. J Ind Stud 1:23-42. doi:10.1080/13662719400000002

Lundvall B, Joseph KJ, Chaminade C, Vang J (Eds.) (2011) Handbook of innovation systems and developing countries: building domestic capabilities in a global setting. Edward Elgar Publishing, Cheltenham

Malecki EJ (1997) Technology and economic development: the dynamics of local, regional, and national change University of Illinois at Urbana-Champaign's Academy for Entrepreneurial Leadership Historical Research Reference in Entrepreneurship

Malerba F (2002) Sectoral systems of innovation and production. Res Policy 31:247-264. doi:10.1016/50048-7333(01)00139-1

Mann CL, Ecker SE, Knight SC (2000) Global Electronic Commerce - a policy primer. Institute for International Economics, Washington DC

Martinez-Pellitero M, Buesa M, Heijs J, Ybaumert T (2008) A novel way of measuring regional systems of innovation: factor analysis as a methodological approach. IAIF Documento de Trabajo 60.

Mastroeni M, Hannon E, Truss C, Conway E, Flood P (2009) The importance of nested scales to national systems of innovation: a cross-national comparison of the UK and Ireland. DRUID Summer Conference, Frederiksberg, Denmark, 17-19 June

Mazzucato M, Perez C (2015) Innovation as growth policy. The triple challenge for Europe: economic development, climate change, and governance, 229

Meesus M, Oerlemans L, van Dijck J (1999) Regional systems of innovation from within an empirical specification of the relation between technological dynamics and interaction between multiple actors in a Dutch region. ECIS, Working Paper No. 99

Morgan K (1997) The learning region: institutions, innovation and regional renewal. Reg Stud 31:491-503. doi:10.1080/ 00343400701232322

Moss TJ, Majerowicz S (2012) No longer poor: Ghana's new income status and implications of graduation from IDA. Center for Global Development Working Paper No 300

Munk KB, Vintergaard C (2004) Venture capitalists in systems of innovation. MPP Working Paper No. 1/2004. Department of Management, Politics and Philosophy, Copenhagen Business School

Nahapiet J, Ghoshal S (1998) Social capital, intellectual capital, and the organisational advantage. Acad Manage Rev 23: 242-266. doi:10.5465/AMR.1998.533225

Nasierowski W, Arcelus FJ (1999) Interrelationships among the elements of national innovation systems: a statistical evaluation. Eur J Oper Res 119:235-253. doi:10.1016/S0377-2217(99)00128-9

Nelson RR (1993) National innovation systems: a comparative analysis. Oxford University Press, Oxford

Nelson RR, Rosenberg N (1993) Technical innovation and national systems. In: Nelson RR (ed) National systems of innovation a comparative study. Oxford University Press, Oxford

Nelson RR, Winter S (1982) An evolutionary theory of economic change. The Belknap Press of Harvard University, London.

Niosi J, Bas T (2001) The competencies of regions: Canada's cluster in biotechnology. Small Bus Econ 17:31-42. doi:10.1023/A:1011114220694

Niosi J, Saviotti P, Bellon B, Crow M (1993) National systems of innovation: in search of a workable concept. Technol Soc 15:207-227. doi:10.1016/0160-791X(93)90003-7

Nooteboom B, DeJong G, Vossen RW, Helper S, Sako M (1998) Competence in mutual dependence. DRUID Summer Conference on Competence, Governance and Entrepreneurship, Denmark, 18-20 June

North DC (1990) Institutions, institutional change and economic performance. Cambridge University Press, Cambridge

OECD (1997) National systems of innovation: Background report. Report DSTI/STP/TIP(97)2/ Paris

Oinas P, Malecki EJ (2002) The evolution of technologies in time and space: from national and regional to spatial innovation systems. Int Reg Sci Rev 25:102-131. doi:10.1177/016001702762039402

Olson M (1996) Distinguished lecture on economics in government: big bills left on the sidewalk: why some nations are rich, and others poor. J Econ Perspect 10:3-24. doi:10.2307/2138479

Oyelaran-Oyeyinka B, Barclay LA (2004) Human capital and systems of innovation in African development. Afr dev rev 16(1):115-138

Pankratz M, Hallfors D, Cho H (2002) Measuring perceptions of innovation adoption: the diffusion of a federal drug prevention policy. Health Educ Res Theory Pract 17:315-326. doi:10.1093/her/17.3.315

Patel P, Pavitt K (1994) National systems of innovation: why they are important, and how they might be measured and compared. Econ Innov New Technol 3:77-95. doi:10.1080/10438599400000004

Pech RJ, Oakley KE (2005) Hormesis: an evolutionary "predict and prepare" survival mechanism. Leadersh Org Dev J 26: 673-687. doi:10.1108/01437730510633737

Penrose E (1959) The theory of the growth of the firm. Oxford University Press, Oxford

Piazolo D (2001) The digital divide. CESifo Forum 2: 29-34.

Piekkola H (2006) Knowledge capital as the source of growth. European Network of Economic Policy Research Institutes, Working Paper No. 43

Piekkola H (2011) Intangible capital: the key to growth in Europe. Intereconomics 4:222-228. doi:10.1007/s10272011-0387-2

Porter ME (1990) The competitive advantage of nations. Macmillan, London

Ricardo D (1817) On the principles of political economy and taxation. London

Robertson PL, YU TF (2001) Firm strategy, innovation and consumer demand: a market process approach. Manag Decis Econ 22:183-199. doi:10.1002/mde.1016

Rodrik D, Subramaniam A, Trebbi F (2004) Institutions rule: the primacy of institutions over geography and integration in economic development. J Econ Growth 9:131-165. doi:10.1023/B:JOEG.0000031425.72248.85

Romer P (1986) Increasing returns and long-run growth. J Polit Econ 94:1002-1037. doi:10.2307/1833190 
Rosenberg N (1996) Perspectives on technology. Cambridge University Press, Cambridge

Rummel RJ (1970) Applied factor analysis. Northwestern University Press, Evanston

Sauer PL, O'Donnell JB (2007) Innovation constructs: an exploratory case study. J Coll Teach Learn 4:33-44

Schumpeter JA (1934) The theory of economic development: an inquiry into profits, capital, credit, interest, and the business cycle. University of Illinois at Urbana-Champaign's Academy for Entrepreneurial Leadership Historical Research Reference in Entrepreneurship

Schumpeter JA (1947) The creative response in economic history. J Econ Hist 7:149-159. doi:10.1017/ S0022050700054279

Seppänen SK (2008) Regional innovation systems and regional competitiveness: an analysis of competitiveness indexes. DRUID-DIME Winter PhD Conference on Geography, Innovation and Industrial Dynamics, January

Shapiro SE, Lasarev MR, McCauley L (2002) Factor analysis of Gulf War illness: what does it add to our understanding of possible health effects of deployment? Am J Epidemiol 156:578-585. doi:10.1093/aje/kwf087

Smith A (1776) The wealth of nations. New York

Smits R, Kuhlmann S (2004) The rise of systemic instruments in innovation policy. Int J Foresight Innov Policy 1:4-32. doi:10.1504/JFIP.2004.004621

Solow R (1956) A contribution to the theory of economic growth. Q J Econ 70:65-94. doi:10.2307/1884513

Spielman DJ, Ekboir J, Davis K, Ochieng CM (2008) An innovation systems perspective on strengthening agricultural education and training in sub-Saharan Africa. Agric syst 98(1):1-9

Stenholm P, Zoltan JA, Wuebker R (2013) Exploring country-level institutional arrangements on the rate and type of entrepreneurial activity. J Bus Ventur 28:176-193. doi:10.1016/j.jbusvent.2011.11.002

Subramaniam M, Youndt M (2005) The influence of intellectual capital on the types of innovative capabilities. Acad Manag J 48:450-463. doi:10.5465/AMJ.2005.17407911

Svendsen GL, Svendsen TG (2003) On the wealth of nations: Bourdieuconomics and social capital. Theor Soc 32:607631. doi:10.1023/B:RYSO.0000004967.97783.c4

Swisher L, Beckstead JW, Bebeau MJ (2004) Factor analysis as a tool for survey analysis using a professional role orientation inventory as an example. J Am Phys Ther Assoc 84:784-799

Teixeira AAC (2014) Evolution, roots and influence of the literature on National Systems of Innovation: a bibliometric account. Camb J Econ 38:184-214. doi:10.1093/cje/bet022

The World Bank and International Finance Corporation (2013) Doing Business 2013: smarter regulations for small and medium-size enterprises. Comparing business regulations for domestic firms in 185 economies (10th edn).

Tidd J (1997) Complexity, networks and learning: integrative themes for research on innovation management. International Journal of Innovation Management 1.doi:10.1142/S1363919697000024

Tidd J (2001) Innovation management in context: environment, organization and performance. Int J Manag Rev 3:169183. doi:10.1111/1468-2370.00062

Tidd J (2006) A review of innovation models. Discussion Paper 1/1. Imperial College London 16

Tidd J, lzumimoto Y (2002) Knowledge exchange and learning through international joint ventures: an Anglo-Japanese experience. Technovation 22:137-145. doi:10.1016/S0166-4972(01)00006-2

Trebilcock MJ (1996) What makes poor countries poor? The role of institutional capital in economic development. Centre for the Study of State and Market, Faculty of Law, University of Toronto

Trebilcock MJ, Prado MM (2011) What makes poor countries poor? Institutional determinants of development. Edward Elgar Publishing

UNCTAD (2011) Science and technology \& innovation policy review_Ghana. http://unctad.org/en/Docs/dtlstict20098_ en.pdf. Accessed 13 Oct 2016

UNIDO (2013) Industrial Development Report. Vienna, Austria

Van Disk J, Hacker K (2003) The digital divide as a complex and dynamic phenomenon. Inform Soc 19:315-326. doi:10.1080/01972240309487

Vashishtha SD, Sharma P (2011) Organisational capital: concept, composition and relevance. International Journal of Business Economics and Management Research 2(8):12-18

Veblen T (1898) Why is economics not an evolutionary science? Q J Econ 12:373-397. doi:10.2307/1882952

Viotti EB (2001) National Learning Systems: a new approach on technical change in late industrializing economies and evidences from the cases of Brazil and South Korea. Science, Technology and Innovation Discussion Paper No. 12, Centre for International Development, Harvard University, Cambridge, MA, USA

Weber KM, Rohracher H (2012) Legitimizing research, technology and innovation policies for transformative change: Combining insights from innovation systems and multi-level perspective in a comprehensive 'failures' framework Res Policy 41(6):1037-1047

Woolcock M (1998) Social capital and economic development: toward a theoretical synthesis and policy framework. Theory and Society 27(2):151-208

World Bank (2011) Africa's future and the World Bank's support to it. Washington: Washington, USA

World Bank (2016) World Development Indicators - Ghana. http://data.worldbank.org/country/ghana. Accessed 13 Oct 2016 Zagler M, Dürnecker G (2003) Fiscal policy and economic growth. J Econ Surv 17:397-418. doi:10.1111/1467-6419.00199

Zimmerman MA, Zeitz GJ (2002) Beyond survival: achieving new venture growth by building legitimacy. Acad Manage Rev 27:414-431. doi:10.5465/AMR.2002.7389921

Zwane AP, Zinman J, Van Dusen E, Pariente W, Null C, Miguel E, Banerjee A (2011) Being surveyed can change later behavior and related parameter estimates. Proc Natl Acad Sci U S A 108:1821-1826. doi:10.1073/pnas.1000776108 